\title{
Wiring olfaction: the cellular and molecular mechanisms that guide the development of synaptic connections from the nose to the cortex
}

\author{
Fernando de Castro* \\ Grupo de Neurobiología del Desarrollo-GNDe, Hospital Nacional de Parapléjicos, Toledo, Spain
}

Edited by:

Pierre M. Lledo, Pasteur Institute,

France

\section{Reviewed by:}

Luca Bonfanti, University of Turin, Italy Valerie Coronas, Université de Poitiers, France

Tatsuhiro Hisatsune, The University of Tokyo, Japan

*Correspondence:

Fernando de Castro, Grupo de Neurobiología del Desarrollo-GNDe, Hospital Nacional de Parapléjicos, Finca "La Peralada" s/n, 45071 Toledo,

Spain.

e-mail:fdec@sescam.jccm.es
Within the central nervous system, the olfactory system fascinates by its developmental and physiological particularities, and is one of the most studied models to understand the mechanisms underlying the guidance of growing axons to their appropriate targets. A constellation of contactmediated (laminins, CAMs, ephrins, etc.) and secreted mechanisms (semaphorins, slits, growth factors, etc.) are known to play different roles in the establishment of synaptic interactions between the olfactory epithelium, olfactory bulb (OB) and olfactory cortex. Specific mechanisms of this system (including the amazing family of about 1000 different olfactory receptors) have been also proposed. In the last years, different reviews have focused in partial sights, specially in the mechanisms involved in the formation of the olfactory nerve, but a detailed review of the mechanisms implicated in the development of the connections among the different olfactory structures (olfactory epithelium, OB, olfactory cortex) remains to be written. In the present work, we afford this systematic review: the different cellular and molecular mechanisms which rule the formation of the olfactory nerve, the lateral olfactory tract and the intracortical connections, as well as the few data available regarding the accessory olfactory system. These mechanisms are compared, and the implications of the differences and similarities discussed in this fundamental scenario of ontogeny.

Keywords: chemotropism, cell adhesion molecule, semaphorin, netrin, anosmin-1, slit, olfactory cortex

\section{INTRODUCTION: A BRIEF SKETCH OF THE OLFACTORY SYSTEM AND ITS DEVELOPMENT}

The basic circuit in the mammalian olfactory system (Figure 1) commences at the olfactory sensory neurons (OSNs) in the olfactory epithelium, a structure that develops from the olfactory placode during embryogenesis. The axons from the OSNs form the olfactory nerve which projects to the olfactory bulb $(\mathrm{OB}$; an evagination from the telencephalon) and forms synapses with the apical dendrites of mitral/tufted cells, giving rise to the OB glomeruli (Cajal, 1890; Greer, 1991). Each one of the approximately 5 million OSNs in a rodent nose expresses only one of the estimated 1300 different olfactory receptor genes (Malnic et al., 1999; Zhang and Firestein, 2002). While those OSNs that express the same olfactory receptor gene are randomly distributed within the nasal cavity, their axons selectively project to only $1 \pm 4$ of the 2000 glomeruli in the $\mathrm{OB}$, reflecting the precise convergence of olfactory nerve axons (for a review, see Mombaerts, 1996).

The primary axons of the projection neurons from the $\mathrm{OB}$ (mitral and tufted cells), preferentially grow into a very narrow region of the ventro-lateral part of the telencephalon to form the lateral olfactory tract (LOT), adjacent to the pial surface (Cajal, 1890; Valverde, 1965; de Castro et al., 1999). Mitral cell axons from the accessory olfactory bulb (AOB; see below for details on the accessory olfactory system) are localized in the deeper lamina of the LOT, segregated from the axons of the OB projection neurons, which are first generated deeper and that then form newly generated neurons in the most superficial lamina of the LOT (between E11.5 and P1-P3 in the mouse: Inaki et al., 2004; Yamatani et al., 2004; Blanchart et al., 2006; Walz et al., 2006a). The axons of the LOT emit collateral branches that reach their target areas in what is collectively known as the olfactory cortex and which contains, mainly, the following structures (from anterior to posterior): the anterior olfactory nucleus, the olfactory tubercle, the piriform cortex, several amygdaloid nuclei and the entorhinal cortex (Devor, 1976; Derer et al., 1977; Scott et al., 1980; Schwob and Price, 1984; Figure 1). While it was initially thought that a stereotypic map of the olfactory epithelium existed in the olfactory cortex, via the $\mathrm{OB}$ (that is, the inputs from OSNs that express the same odor receptor map to precise clusters of target neurons in the olfactory cortex), this concept is now not so clear (Zou et al., 2001, 2008). Finally, the definitive layering of the $\mathrm{OB}$ depends on the arrival of tangential migrating cells from the telencephalic subventricular zone, the prospective interneurons of the $\mathrm{OB}$ and the only neurons of the $\mathrm{OB}$ that are generated outwards (reviewed in Goldman and Luskin, 1998).

The different elements of the olfactory cortex develop a complex pattern of interconnections (Figure 1), in which the following elements can be distinguished:

(i) local and intraregional corticocortical association projections (for a review, see Shipley et al., 2004);

(ii) extrinsic projections from the anterior olfactory nucleus, the piriform cortex and the lateral enthorinal cortex project back to the $\mathrm{OB}$, both ipsi- and contralaterally (for a review, 


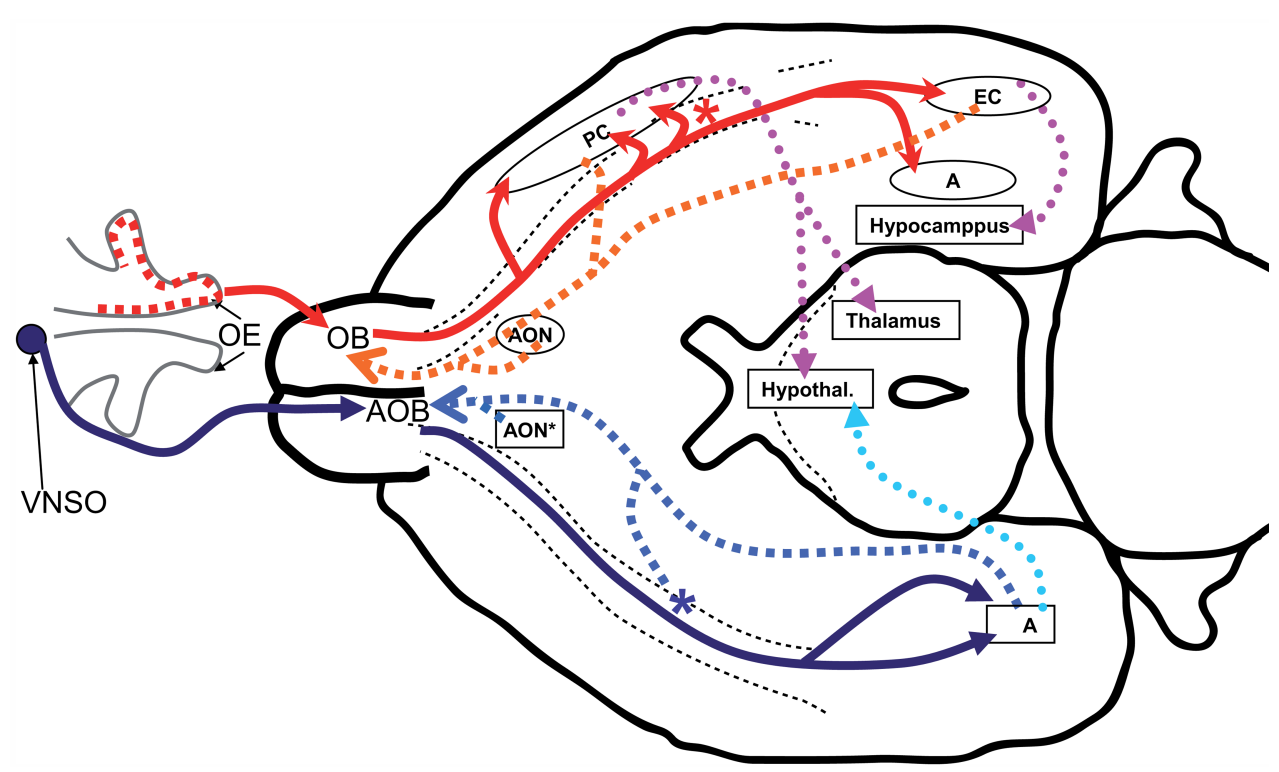

FIGURE 1 | General scheme of the connections of the olfactory system and the accessory olfactory system. The axons from the OSNs (red dots within the olfactory epithelium, EO) project to the olfactory bulb (OB), forming the olfactory nerve. The projection neurons from the $\mathrm{OB}$ send their axons (the lateral olfactory tract, LOT) to the different structures of the olfactory cortex, among them the anterior olfactory nucleus (AON), the taenia tecta, the olfactory tubercule, the piriform cortex $(\mathrm{PC})$, the amygdaline complex $(\mathrm{A})$ and the entorhinal cortex $(\mathrm{EC})$, and the nucleus of the lateral olfactory tract (nLOT; red asterisk). In both cases, the olfactory nerve and the LOT are represented with gross red curved arrows. Neurons from the olfactory cortex and the nLOT project back to the OB (gross orange curved arrows). Main intracortical connections (violet dotted arrows) are towards parts of the neocortex, hippocampus, thalamus and the hypothalamus, as well as to the neocortex and the contralateral olfactory cortex (forming the anterior commissure, not represented). The axons arising from the vomeronasal organ (VNSO) form the vomeronasal nerve and project to the accessory olfactory bulb (AOB). The projection neurons from this send their axons (as part of the LOT) to the AON and the nLOT (blue asterisk), and to A (gross blue curved arrows), while axons from neurons from these three cortical structures project back to the AOB (light blue dotted arrows). The projections from the accessory olfactory cortex reach the hypothalamus (turquoise dotted arrow) and the nucleus of the lateral olfactory tract. This schema is adapted from Paxinos (2004). see Shipley et al., 2004). These projections are denser from the rostral structures of the primary olfactory cortex than from the caudal ones (Shipley and Adamek, 1984);

(iii) contralateral projections towards other regions of the olfactory cortex, including the commissural fibres, mainly from the rostral parts of the piriform cortex to the contralateral cortex (Shipley et al., 2004);

(iv) extrinsic projections towards the neocortex (insular and orbito-frontal cortices), the mediodorsal thalamic nucleus and the hypothalamus (for a review, see Shipley et al., 2004).

Two classical and opposite hypothesis explain how this organization of the olfactory system arises during development. On the one hand, the "protomap" theory predicts that the olfactory epithelium, OB and olfactory cortex are simultaneously and independently organized, through an intrinsic developmental programme in each structure, possibly involving major molecular determinants (Rakic, 1988; Fukuchi-Shimogori and Grove, 2001; Rakic et al., 2009). On the other hand, the "protocortex" theory that this development depends that on extrinsic elements (O'Leary, 1989) and it predicts that the development of the OB would be a secondary process, dependent upon the arrival of the OSN fibres from the olfactory epithelium, and the subsequent arrival of the LOT fibres to the olfactory cortex would be necessary to induce its own differentiation. Few years ago, we extensively reviewed the bulk of the experimental data to suggest that the protomap hypothesis explains how the olfactory system develops, with the influence exerted by the olfactory epithelium on the $\mathrm{OB}$ only becoming relevant once the different structures (olfactory epithelium, OB, olfactory cortex) have been independently generated (López-Mascaraque and de Castro, 2002, 2004). In this sense, the latest genetic approaches, such as mice with a "monoclonal nose" (in which more than $95 \%$ of the OSNs express a single odorant receptor), seem to confirm that mechanisms intrinsic to the $\mathrm{OB}$ are responsible for building glomeruli (Fleischmann et al., 2008), while a member of the TGF family that is secreted by OSN axons selectively induces the outgrowth of the dendrites from mitral and tufted cells in the embryo (Tran et al., 2008).

As fundamental tool for our purpose in the works cited above, we summarised the timescale of the main developmental events of the olfactory system, and scaled them for the rat and the mouse, in order to offer a template for ulterior research (López-Mascaraque and de Castro, 2002, 2004). In brief, the chronology of the olfactory system development for the mouse would be considered as follows:

(i) the olfactory placode and the first signs of neurogenesis in the presumptive olfactory epithelium starts around E9.5, while the first neurons are generated by E11 at the $\mathrm{OB}$ and by E10 at the olfactory cortex; 
(ii) while the first OSN axons are identified before E10.5, they coalesce to form a clear olfactory nerve forms between $\mathrm{E} 11$ and E12, and this enters in the $\mathrm{OB}$ to form synapses around E13.5;

(iii) the LOT is first observed between E11.5-E12, covers the surface of the olfactory cortex by E13.5 and gives rise to collaterals by E14.5 to colonise this.

Due to the large variety of cell populations and structures, a similar timescale remains to be compiled for the different elements of the olfactory cortex. The axons of the olfactory nerve initially distribute diffusely within the OB, but by E17.5 in the mouse they start to topographically cluster to specific zones of the glomerular layer, the protoglomeruli, which progressively condense and separate each other to reach the final appearance of olfactory glomeruli in a process that extends between E18.5 and P14.5 (St John et al., 2002).

The aim of this review is to synthesise all the mechanisms involved in generating the connections between the different structures in the olfactory system. In each epigraph of this review (the olfactory nerve, the LOT and the intracortical connexions), we will review what can be considered to be the "special" mechanisms, as well as all the contact-mediated (permissive and non-permissive) and long-range cues (attractants and repellents) relevant for these developmental processes (Tessier-Lavigne and Goodman, 1996). Partial reviews with a similar goal to this work have been published elsewhere (López-Mascaraque and de Castro, 2002, 2004; St John et al., 2002; Henion and Schwarting, 2007; Schwarting and Henion, 2008), but here we provide an updated review of the axon guidance that wires the entire olfactory system, from the olfactory epithelium to the $\mathrm{OB}$, from the $\mathrm{OB}$ to the olfactory cortex and within the olfactory cortex. Finally, we will also offer a view of the molecular basis of the development of connectivity in the accessory olfactory system.

All the data reviewed in this article are summarised in Table 1. To gift agility to the text, we do not refer the temporal expression patterns of the different molecules reviewed along the text, only in that cases in which these patterns of expression differs from the timescale of the main developmental events summarised above and elsewhere (López-Mascaraque and de Castro, 2002, 2004).

\section{FROM THE OLFACTORY EPITHELIUM TO THE OLFACTORY BULB: CELLULAR AND MOLECULAR MECHANISMS INVOLVED IN THE FORMATION OF THE OLFACTORY NERVE}

As outlined above, the OSNs are the only cells that project from the olfactory epithelium to the $\mathrm{OB}$, and the bulk of these axons form the olfactory nerve, whose nerve endings form synapses with the apical dendrites of the mitral and tufted cells to form the OB glomeruli (Cajal, 1890; Greer, 1991). Since their discovery less than 20 years go (Buck and Axel, 1991), the olfactory receptors constitute one among best known and amazing families of genes. As briefly outlined above, approximately 1300 genes encode the different olfactory receptors in rodents, and each of the approximately five million OSNs in a rodent nose expresses a single olfactory receptor (Malnic et al., 1999; Zhang and Firestein, 2002), although the number of olfactory receptors in humans is only 350 and show a convergence ratio of 16:1 glomeruli/OR instead of the 2:1 ratio in the mouse (Maresh et al., 2008). Those OSNs that express the same olfactory receptor are randomly distributed within the nasal cavity although their axons are highly convergent, projecting to only $1-4$ of the $2000 \mathrm{OB}$ glomeruli (for a review, see Mombaerts, 1996). Olfactory receptors are expressed prior to the final maturation of OSNs defined by OMP expression (Iwema and Schwob, 2003), and have been proposed to play a dual/complementary role in OSN selection:

(i) on the one hand, an OSN that does not express an olfactory receptor will die, reflecting a means of positively selecting OSNs that express at least one olfactory receptor;

(ii) on the other hand, the identity of OSN axons that co-express two olfactory receptors at the same time is disturbed, which causes defects in its projection and in the stablity of its contacts, and exerting a negative selection for OSNs that express more than one olfactory receptor (Feinstein et al., 2004). This second property also suggests a role for olfactory receptors in axonal guidance.

In recent years, olfactory receptors have been identified in the growth cones of the OSN axons, leading to the hypothesis that they are involved in final target recognition and even, in the navigation of the axons towards the $\mathrm{OB}$, which shifts along the antero-posterior axis in response to changes in the olfactory receptor-derived cAMP signals (Barnea et al., 2004; Strotmann et al., 2004; Imai et al., 2006; for a review, see Imai and Sakano, 2008). However, this latter issue remains to be clarified since there is currently no clear mechanism by which the olfactory receptors could provide identity to the OSN growth cones. Hence, ad maximum olfactory receptors would merely be involved in the final processes in forming the projection from the olfactory epithelium to the $\mathrm{OB}$ via homophilic and heterophilic interactions, giving rise to what has been baptised as the "contextual model of axon sorting" (Feinstein and Mombaerts, 2004; Mombaerts, 2006). The only means by which the olfactory receptors could influence other aspects of OSN behaviour is through the G protein/cAMP cascade (Chesler et al., 2007) or other mechanisms to produce cAMP via the olfactory nerve (Imai et al., 2006; Dal Col et al., 2007; Zou et al., 2007). In this sense, we will study how cell activity may influence in the formation of the olfactory nerve in more detail below.

One of the enigmas regarding the formation of the connectivity between the olfactory epithelium and the OB is that when the OSN axons approach the presumptive $\mathrm{OB}$ (at E14 in the rat), only a few pioneer axons enter this target. Thus, the vast majority of the nerve fibres do not immediately invade this tissue but rather, they only do so after a protracted delay of several days. This waiting period is sufficient time for incoming axons to accumulate, finally entering the $\mathrm{OB}$ when this becomes permissive to the axons (Doucette, 1989; Santacana et al., 1992; Valverde et al., 1992; Renzi et al., 2000; Conzelmann et al., 2001). At present, there are few molecular explanations for this protracted wait, or for the involvement of either contact-mediated mechanisms (e.g. via Tenascin) or those involving chemotropic molecules (such as secreted semaphorins and Netrin-1) in this process (Renzi et al., 2000; Watanabe et al., 2006; Shay et al., 2008; for a detailed review on the role of adhesion and secreted molecules in the guidance of OSN axons, see below). 
Table 1 | Comparative effects of molecules in the formation of the olfactory nerve, the LOT and the intracortical connections of the olfactory cortex.

\begin{tabular}{|c|c|c|c|c|}
\hline & Olfactory nerve & LOT & Intracortical & Accessory olfactory system \\
\hline Special mechanisms & Olfactory receptors: role not clear & Lot1+-guidepost cells & - & - \\
\hline \multirow[t]{4}{*}{$\begin{array}{l}\text { Contact-mediated } \\
\text { mechanisms }\end{array}$} & $\begin{array}{l}\text { OCAM: minor changes } \\
\text { NrCAM, CLH1: disturbed guidance }\end{array}$ & $\begin{array}{l}\text { NCAM, NrCAM, OCAM } \\
( \pm \text { TAG-1): not demonstrated }\end{array}$ & $\begin{array}{l}\text { NrCAM: ACa } \\
\text { defasciculated and } \\
\text { shifted }\end{array}$ & - \\
\hline & Cadherin/Protocadherin-2: not clear & - & Celsr3: AC not formed & - \\
\hline & & & $\begin{array}{l}\text { Sek4 (Eph-related): no } \\
\text { effect }\end{array}$ & \\
\hline & $\begin{array}{l}\text { Sema7A: suggested (via PlexinC1 } \\
\text { and others) }\end{array}$ & $\begin{array}{l}\text { Sema7A: orientation, growth } \\
\text { > collateralization }\end{array}$ & - & $\begin{array}{l}\text { Sema7A: suggested in VNSO } \\
\text { (via PlexinC1 and others) }\end{array}$ \\
\hline \multirow[t]{6}{*}{ Secreted molecules } & Sema3A (via Neuropilin-1) & $\begin{array}{l}\text { Sema3A: not effect } \\
\text { Sema3B: attractant } \\
\text { Sema3F: repellent }\end{array}$ & $\begin{array}{l}\text { Sema3A: no effect } \\
\text { Sema3B: ACa } \\
\text { defasciculated and } \\
\text { shifted } \\
\text { Sema3F: ACa } \\
\text { defasciculated and } \\
\text { shifted via Neuropilin-2 } \\
\text { (no-1) } \\
\text { PlexinA4: ACa absent }\end{array}$ & $\begin{array}{l}\text { Sema3F (via Neuropilin-2): } \\
\text { minor effects in VNN }\end{array}$ \\
\hline & Retinoic Acid: axon elongation & - & & - \\
\hline & Wnt5a: axon elongation & - & $\begin{array}{l}\text { Wnt/Frizzled-3: AC } \\
\text { absent }\end{array}$ & - \\
\hline & $\begin{array}{l}\text { IGF-1: attractant } \\
\text { (OSNs arriving lateral OB) }\end{array}$ & - & & - \\
\hline & HGF: axon outgrowth & & & \\
\hline & CXCR4/SDF-1: no effect & & & \\
\hline
\end{tabular}

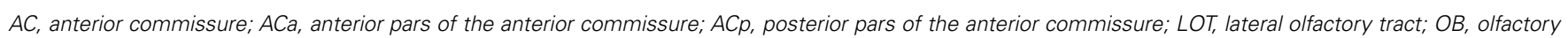
bulb; OSN, olfactory sensory neuron; VNN, vomero-nasal nerve; VNSO, vomero-nasal organ.

\section{CONTACT-MEDIATED MECHANISMS AND THE FORMATION OF THE OLFACTORY NERVE}

Apart from what might be considered as a "special" mechanism for the guidance and development of the olfactory nerve (via the olfactory receptors), different contact-mediated mechanisms have been proposed to influence in this developmental event to date. More than a decade ago, cell-cell adhesion and different extracellular matrix molecules (cadherin, tenascin) were proposed to be relevant for the formation of the olfactory nerve (Gong and Shipley, 1996; Treloar et al., 1996; Yoshihara et al., 1997; Akins and Greer, 2006; Akins et al., 2007; Shay et al., 2008). Among these, maybe the most interesting molecules are Tenascin-C, which inhibits the premature invasion of 
glomerular layer for about 4 days and allows the proper formation of olfactory glomeruli on time (Treloar et al., 2009), and the Olfactory Cell Adhesion Molecule (OCAM), which must be down-regulated in the dendrites of mitral and tufted cells to allow $\mathrm{OCAM}^{+}-\mathrm{ON}$ axons to form synapses, and vice versa (Treloar et al., 2003). However, later experiments show that disrupting the expression of OCAM (either knock-out or over-expression) only produces minor changes in the compartmentalization of OSN axons within the OB, including an increase in the number of $\mathrm{OB}$ glomeruli innervated by heterogeneous OSN axons but not in their convergence to the target structure (Alenius and Bohm, 2003; Walz et al., 2006b). The polysialated form of NCAM, PSA-NCAM, has been suggested to be involved in the outgrowth of axons of immature OSNs and the initial assembly of the olfactory nerve (Whitesides and LaMantia, 1998; Aoki et al., 1999; St John et al., 2002; Bonfanti, 2006). The null mutation of genes encoding cell recognition molecules of the L1 family, like CHL1 and NrCAM, disturbs the guidance of the olfactory nerve, although in the $\mathrm{CHL1}^{-/-} / \mathrm{NrCAM}^{-/-}$double-mutant mice there is no enhancement of the single mutant's phenotype (Heyden et al., 2008). Likewise, the recent detection of calcium-dependent adhesion molecules in the olfactory system, like cadherins (Akins et al., 2007), and especially protocadherin-20 in newly differentiated OSNs (Lee et al., 2008), has opened new perspectives to explain the formation of the olfactory nerve. It has also been shown that null mutation of the gene encoding the enzyme that produces the glycan lactosamine $\left(\beta 1,3-N^{\prime}\right.$-acetylglucosaminyltransferase $\left.1-G n T 1-\beta 3 G n T 1-\right)$ results in the normal outgrowth of olfactory axons to the $\mathrm{OB}$, although at least some of them (i.e. those innervating P2 and I7 glomeruli) do not penetrate it. Consequently, under these conditions no synapses are formed with the receptive elements of the OB glomeruli (Henion et al., 2005).

These seem to be the most relevant findings regarding the role of contact-mediated mechanisms in the formation of the projection from the olfactory epithelium to the OB. However, the ephrins are another classic family of contact/adhesion molecules that may fulfil a secondary role in the formation of the olfactory nerve. Indeed, null mutation of ephrinA3 and ephrinA5, both expressed by the axons of OSNs, merely alters the fine convergence of the axons to their correct glomeruli within the OB (Cutforth et al., 2003), in accordance with the role of these molecules in forming topographical projections in other sensory systems (for a review, see Holmberg and Frisén, 2002; Price et al., 2006). It has been recently shown that BIG-2/contactin-4, a glycoprotein of the immunoglobulin superfamily, is expressed by a subpopulation of OSNs and that this expression is closely correlated with the expression of olfactory receptors. Accordingly, in $B I G-2^{-/-}$mice the OSNs expressing the same olfactory receptor frequently innervate multiple glomeruli at ectopic locations, suggesting that this axonal molecule is crucial for the formation and maintenance of a functional odour map in the OB (Kaneko-Goto et al., 2008).

It is interesting that from the combination of only six axonal markers differentially expressed by the OSNs axons, including the aforementioned molecules (Zhou et al., 1999; Cutforth et al., 2003; Henion et al., 2005) together with Neuropilin-1, a receptor for the secreted semaphorins (see below Schwarting et al., 2000), and Kirrel2 and Kirel3, new members of the immunoglobulin superfamily (Serizawa et al., 2006), 700 possible combinations of "molecular identities" arise for OB glomeruli. These almost perfectly match the approximately 1000 different types of olfactory receptors discovered to date (Chen and Flanagan, 2006; Schwarting and Henion, 2008). However, while these molecules might participate in establishing the main domains within the OB, they do not seem to take part in the navigation of olfactory nerve axons towards glomeruli, with the exception of Neuropilin-1 (see below). Moreover, once in the $\mathrm{OB}$ intrinsic activity is likely to contribute to refine the initial targeting.

\section{SECRETED MOLECULES INVOLVED IN THE DEVELOPMENT OF THE OLFACTORY NERVE}

Recent data seems to clarify the need for secreted cue/s from the OB for the formation of the olfactory nerve (Luxenhofer et al., 2008). The first reports regarding the relevance of secreted molecules for the formation of the olfactory nerve focused on the potent Semaphorin chemorepellent, Sema3A, the absence of which distorts the convergence of the OSNs axons to the correct glomeruli, an effect thought to be mediated by Neuropilin-1 (Schwarting et al., 2000, 2004; Taniguchi et al., 2003). The joint activity of two other well known chemorepellents, Slit-1 and Slit-2, is thought to control the normal convergence of olfactory axons in the $\mathrm{OB}$ (Cho et al., 2007; N'Guyen-Ba-Charvet et al., 2008), probably via their receptors Robo-1 and Robo-2 (expressed in a high-dorsomedial to low-ventrolateral gradient across the olfactory epithelium). Indeed, the mutation of Slit-1 or Robo-2 produces latero-ventral regional disturbances in the projection of the olfactory nerve onto the $\mathrm{OB}$, while single mutation of the remaining members of these families only generate minor disturbances, maybe due to the high degree of redundancy (Cho et al., 2007). It has been proposed in Drosophila that a code of the three Robos controls the pattern of OSN projections to the glomeruli of the olfactory lobe (Jhaveri et al., 2003). However, Robo-2 is not expressed by all the OSNs in mammals and a combinatorial code of Robos in this cell population has not been identified to date. Moreover, although Robo-1 is not expressed by OSNs, its null mutant, together with that of Robo-2, has a more pronounced phenotype (Cho et al., 2007; N'Guyen-BaCharvet et al., 2008). Together, these data suggest a relevant role for the Slit/Robo system in the guidance of olfactory nerve axons during development.

Two potent morphogens active in the early development of the central nervous system (CNS), Retinoic Acid and Wnt5a, have been recently shown to be necessary for the OSNs to elongate their axons. While the first was tested in E14 mice (Luxenhofer et al., 2008), the second was shown to be relevant in this process from the earliest moments of the olfactory nerve formation (E10 in the mouse) until adulthood (Rodriguez-Gil and Greer, 2008). The list is completed with two growth factors recently demonstrated to act in the development of the olfactory nerve. While the hepatocytic growth factor (HGF) is necessary for the correct outgrowth of OSN axons (Giacobini et al., 2007), the insulin growth factor (IGF) selectively attracts the axons of the OSNs to innervate the lateral OB (Scolnick et al., 2008).

It seems remarkable that other molecules with important roles in cell migration and axonal guidance during CNS development do not affect the formation of the olfactory nerve at all, like CXCR4/ SDF-1 (for a recent review, see Li and Ransohoff, 2008; Tiveron and Cremer, 2008), while this molecule does modulate the migration of 
$\mathrm{GnRH}^{+}$neurons along this nerve towards the hypothalamus (Toba et al., 2008). This is also the case of Netrin-1, which is expressed in the olfactory system during development and that via DCC, influences the migration of $\mathrm{GnRH}^{+}$-neurons along the olfactory nerve, although this molecule has yet to be shown to direct the outgrowth of OSN axons (Astic et al., 2002; Schwarting et al., 2004).

Finally, activation of the GABA-B receptors expressed by the OSNs from E16 to adulthood is a physiological means to limit the outgrowth of OSN axons as they enter the OB, and they are activated by the GABA released by juxtaglomerular cells (Priest and Puche, 2004).

The most relevant data regarding this epigraph have been schematized in Figure 2.

\section{THE ACTIVITY AND DEVELOPMENT OF THE OLFACTORY NERVE}

The role of activity in the guidance of axonal growth cones during development has been studied extensively in the last decade (for a review, see Zhang and Poo, 2001; Zheng and Poo, 2007). In terms of the olfactory nerve, the role of activity has been studied via different knockout mice although clear conclusions have yet to be reached (for a review on the different positions adopted: Chesler et al., 2007). In this sense, OSN axons converge normally at $\mathrm{OB}$ glomeruli in a null mutant of the $\mathrm{G}$ protein subunit $\left(\mathrm{G}_{\mathrm{OLF}}\right.$ : Belluscio et al., 1998), and only minor defects are observed when the cyclic nucleotide-gated channel subunit (OCN1) is deleted (Baker et al., 1999; Lin et al., 2000; Zheng et al., 2000). The deletion of adenylyl cyclase 3 (Ac3) produces a stronger disorganization in the convergence of the olfactory fibres to the correct $\mathrm{OB}$ glomeruli (Trinh and Storm, 2003; Dal Col et al., 2007), which could be at least part due to the fact that OSNs in these $A c 3^{-1-}$ mice completely lack Neuropilin-1 (Dal Col et al., 2007). Likewise, it has been proposed that the production of CAMP due to the activation of $\mathrm{G}$ protein is required for the convergence of OSNs to the correct OB glomeruli (Chesler et al., 2007).

Contradictory effects are produced by blocking different potassium channels. While a null mutation of the shaker potassium channel, Kvi.3, merely alters the refinement of the OSN projection to the $\mathrm{OB}$ in postnatal development (P0-P41) and not their guidance towards the OB (Biju et al., 2008), over-expression of the inward rectifier channel Kir2.1blocks olfactory receptor activity and produces major changes in the development of the ON (Yu et al., 2004).

Although the survival of OSNs depends on their activity (Zhao and Reed, 2001; Reed, 2004), the role that the activity of OSNs might fulfil in the development of the olfactory nerve, and in the correct navigation of OSN axons towards the OB glomeruli does not seem to be determinant (Mombaerts, 2006). This is even more so when we consider that the activity of OSNs regulates the expression of receptors like Neuropilin-1 (either that derived from the cytoplasmic levels of cAMP or by deleting Ac3: Imai et al., 2006; Dal Col et al., 2007). Indeed, changes in the expression of the receptors of chemotropic or contact molecules could be the direct response of the changes observed in models where activity is absent.

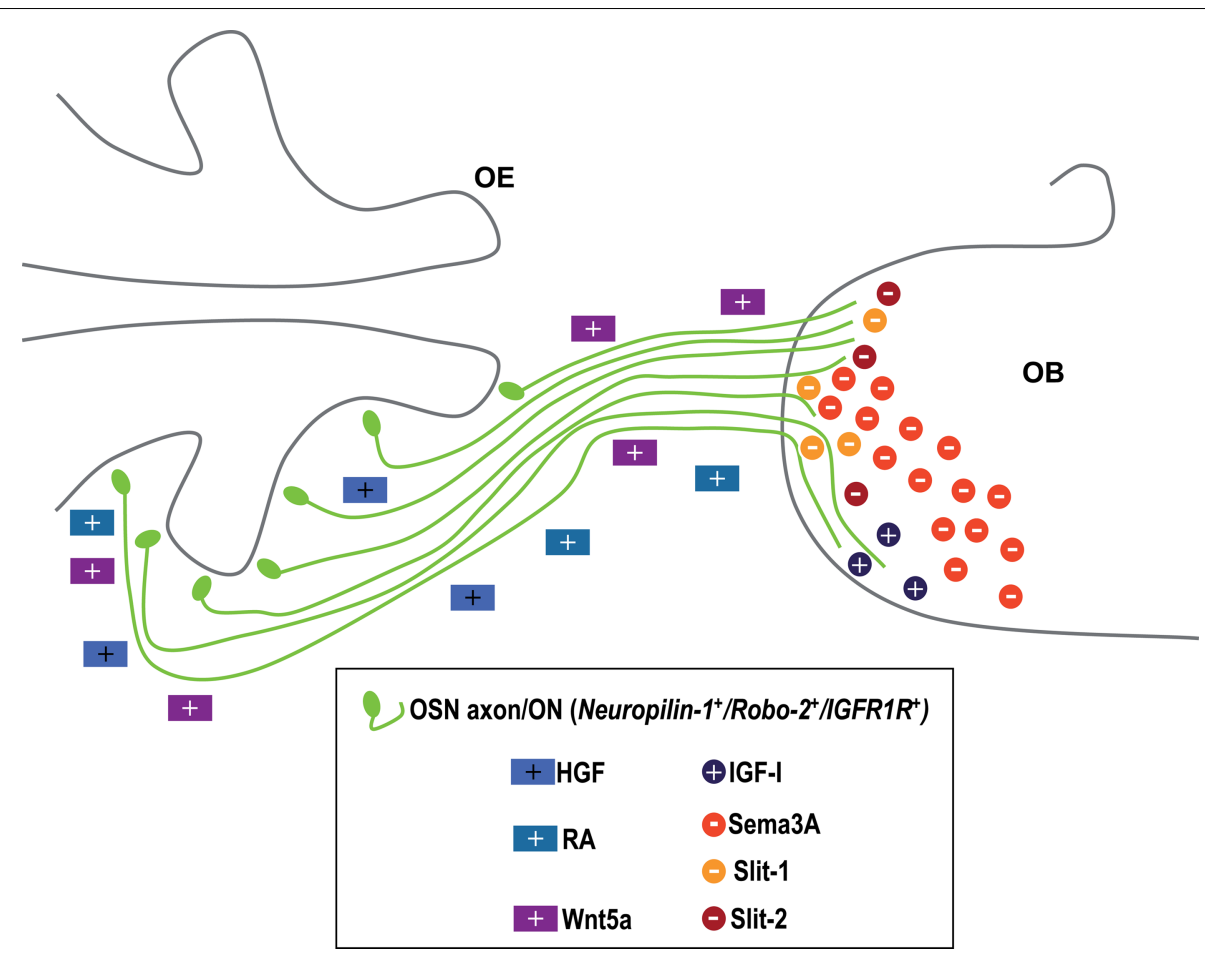

FIGURE 2 | Secreted cues involved in the formation of the olfactory nerve. The OSNs are located in the olfactory epithelium, and their axons project to the olfactory bulb $(\mathrm{OB})$ to form the olfactory nerve (in green). Axonal elongation depends on the action of retinoic acid (RA), Wnt5a and hepatocytic growth factor (HGF), all of them represented as coloured squares. Once in the OB, some axons are attracted towards the lateral part of this structure by insulin growth factor I (IGF-I), while Sema 3A, Slit-1 and Slit-2 co-act repelling them and avoiding the axons to sparse deeper in the OB. These chemotropic molecules have been represented as circles. + , attractant or favouring cue. - , repellent. See text for details. 
Finally, postsynaptic neurons (mitral and tufted cells in $\mathrm{OB}$ glomeruli) control the convergence of the olfactory nerve into the OB. Although the ON transactivation does not produce a significant disturbance of this convergence (Costanzo, 2000), the distribution of the P2 afferents is highly disrupted when postsynaptic neurons have been selectively eliminated (Ardiles et al., 2007). Such an effect is in agreement with the hypothetical role of extrinsic signals produced by the postsynaptic targets of OSNs in regulating their survival and turnover (Schwob et al., 1992; Weiler and Farbman, 1999; Carson et al., 2005).

In summary, although the activity of OSNs is not relevant for the navigation of their axons towards the $\mathrm{OB}$, it is for the final refinement of these connections once they are within the $\mathrm{OB}$. As a corollary of this epigraph on the olfactory nerve, it has been suggested that the cues that guide OSN axons to correctly form synapses within the $\mathrm{OB}$ are preserved throughout the life of the animal (Gogos et al., 2000; Potter et al., 2001).

\section{FROM THE OLFACTORY BULB TO THE OLFACTORY CORTEX: CELLULAR AND MOLECULAR MECHANISMS GUIDING THE AXONS OF THE LATERAL OLFACTORY TRACT}

The axons emitted by the projection neurons of the $\mathrm{OB}$ make up the LOT, the only pathway followed by these axons to colonise the different structures of the primary olfactory cortex. It has been suggested that axons from the AOB projection neurons are located deep within the LOT and that they act as pioneer axons for the axons from the OB projection neurons. This has been shown by studying the timing of the formation of the LOT and the arrival of mitral cell axons to their targets areas within the olfactory cortex (Bayer, 1983; Schwob and Price, 1984; López-Mascaraque et al., 1996). However, the axons of the mitral cells form the LOT in the absence of AOB axons (Sugisaki et al., 1996), which suggests that intrinsic signals from the telencephalon are more likely to govern the formation of the LOT (Jiménez et al., 2000). Indeed, in the absence of Pax6, a transcription factor implicated in the initial development of the OB and the LOT, a remnant OB develops that does not evaginate macroscopically and that has been called the OBLS (OB-like structure), due to a lack of migration of the mitral cell precursors (Jiménez et al., 2000; Nomura and Osumi, 2004). In these mutants, we demonstrated that the axons of the mitral and tufted cells project towards the olfactory cortex and form a LOT (Jiménez et al., 2000). By contrast, when the expression of Lhx2 is eliminated, an OBLS forms but the axons of its projection neurons fail to form a LOT and they grow no more than few microns in length (Saha et al., 2007). Thus, internal mechanisms from the OB projection neurons appear to permit the outgrowth of their axons, and consequently, external cues present in the environment must orient this outgrowth towards the different target cells in the primary olfactory cortex.

\section{CONTACT-MEDIATED MECHANISMS IN THE DEVELOPMENT OF THE LOT}

Obviously, cell adhesion molecules are good candidates to act as contact mediated signals in the formation of the LOT, particularly molecules such as NCAMH, OCAM, Nr-CAM and PSANCAM (Seki and Arai, 1991; Stoeckli and Landmesser, 1995; von Campenhausen et al., 1997). While these molecules could act together, they might act in combination with TAG-1/axonin-1
(Stoeckli and Landmesser, 1995), although to date they have not been directly implicated in the formation of the LOT. Other important contact-molecules like reelin or members of the ephrin/Eph signalling system do not appear to participate in the formation/ targeting of the LOT (Caviness and Sidman, 1972; St John and Key, 2001). We also showed that different components of the extracellular matrix, such as laminin, fibronectin and anosmin-1 promote a different degree of mitral cell axon outgrowth in vitro (SoussiYanicostas et al., 2002). Finally, the lack of the GPI-membrane anchored semaphoring, Sema7A, results in the rostrocaudal outgrowth of LOT axons, although they are not oriented and their collaterals fail to form (Pasterkamp et al., 2003).

A singular contact-mediated mechanism has been proposed to guide mitral and tufted cell axons, the so-called guide-post cells that are specific to the LOT in the general framework of the olfactory system (Sato et al., 1998; Zhou et al., 2008; for a recent review, see Colón-Ramos and Shen, 2008). Such cells are identified with the monoclonal antibody, lot 1, as a subset of early-generated neurons formed exclusively in the neocortex and that migrate to their position in the basal telencephalon where they enclose the LOT (Sato et al., 1998; Hirata et al., 2001). These lot1-positive cells seem to form a restriction in most areas of the olfactory cortex beyond which LOT axons do not grow (Hirata et al., 2001). Hence, these lot1-positive cells may produce factors that either attract or support axonal outgrowth (Hirata et al., 2001). However, the true physiological role of the lot1-positive guide posted cells in the development of the LOT remains unclear and indeed, blockage with the $\mathrm{mAB}$ lot1 does not alter the formation of the LOT in organotypic cultures (Hirata et al., 2001). Moreover, in the knockout for the Lhx2 transcription factor there are severe defects in the localization of the lot1-positive cells in the basal telencephalon (together with the almost absence of the LOT, see above), either due to the null mutation of $L h x 2$ itself or that indirectly of secreted Netrin-1 and Sema3F (which determine the physiological position of lot1-positive cells in the brain) although in the mutants for these two chemotropic molecules the LOT itself forms with no major defects (Kawasaki et al., 2006; Saha et al., 2007; Ito et al., 2008). Hence, given the weak heterogeneity expected in the LOT projection when compared to the olfactory nerve, it seems more likely that such contact-mediated mechanisms contribute less to the formation of first tract than in the case of the ON (Potter et al., 2001; Treloar et al., 2002).

In Figure 3 are included the most important mechanisms reviewed in this epigraph.

\section{SECRETED CUES INVOLVED IN THE FORMATION OF THE LOT}

Studying the guidance of axons from the OB projection neurons led to the first description of a chemorepellent effect in the mammalian CNS, repulsion exerted by the septum of the forebrain. From that moment on, the relevance of secreted cues for the formation of the LOT was assumed, although the nature of the molecule responsible for this effect remained unknown (Pini, 1993). The first chemorepellent to be identified for LOT axons was Slit-2, which was suggested to be the substance secreted by the septum. Slit-2 acts through its functional receptor Robo- 1 and it is the N-terminal domain that is the active fragment of the protein (Li et al., 1999; N'Guyen-Ba-Charvet et al., 1999, 2001). After years in which this 


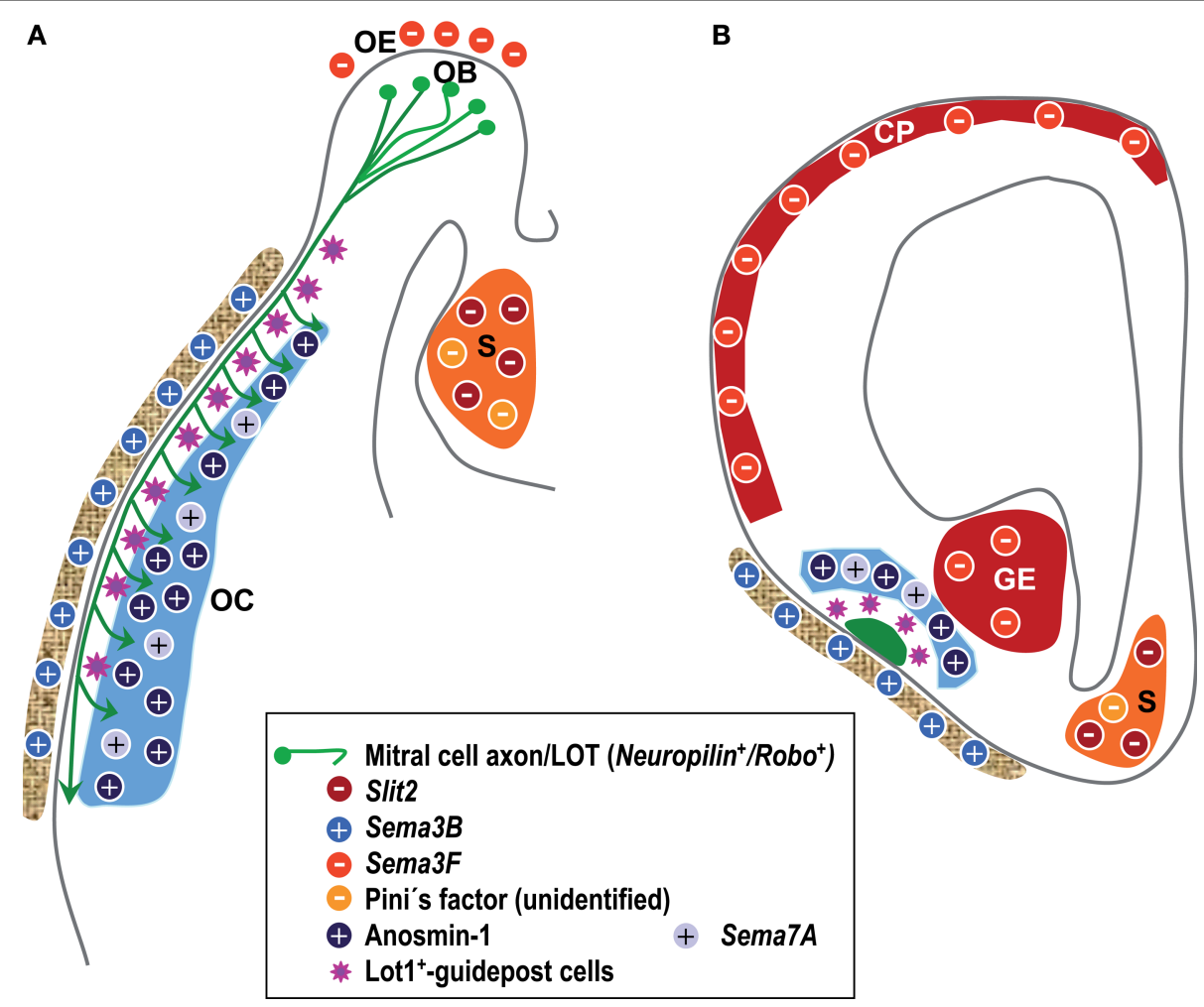

FIGURE 3 | Factors guiding the axonal outgrowth from projection neurons of the olfactory bulb to the olfactory cortex. While (A) represents a horizontal section of the head to show the olfactory structures $(\mathrm{OE}, \mathrm{OB}$ and $\mathrm{OC})$, (B) represents a coronal one. Mitral and tufted cells and their axons (which form the lateral olfactory tract, LOT) are represented in green. Different chemorepellents (red, orange and brown symbols, with " - " inside) avoid LOT axons to invade different cortical structures (septum, S; ganglionic eminence, GE; and cortical plate,
$\mathrm{CP}$, circumscribing them to a position the very surface of the telencephalic vesicle. This position of the LOT is assured by lot1+cells (violet stars) and chemoattractants like Sema 3B (secreted by progenitors of the skull bones) and Anosmin-1 (produced by the olfactory cortex). Both, Anosmin-1 and Sema 7A are the only two known factors ruling the formation of collaterals from the LOT axons (green arrows in (A)) to invade their target areas in the $\mathrm{OC}$ (see text for details). These schemas have been adapted from López-Mascaraque and de Castro $(2002,2004)$. effect of Slit remained unclear ${ }^{1}$ (Sugisaki et al., 1996; Hirata et al., 2001; Patel et al., 2001), in vivo studies on single and in particular double mutants for Slit-1 and Slit-2, demonstrated major disturbances of the LOT formation (Slit $1^{-/-}$; Slit $2^{-/-}$), including the contralateral crossover of some axons. These alterations are less remarkable when only Slit2 is knocked-out (Slit1 ${ }^{+-}$; Slit2 $2^{-/-}$, no LOT axons crossing over to the contralateral hemisphere (N'GuyenBa-Charvet et al., 2002; Fouquet et al., 2007). It is remarkable that the double mutant of the ligands (Slit1 ${ }^{--}$; Slit2 ${ }^{--}$) shows a stronger phenotype that the double mutant of their Robo receptors $\left(\right.$ Robol $^{-l-}$; Robo $^{-l-}$ ), and in none of these double mutants is LOT axon growth along the rostrocaudal axis affected (Fouquet et al., 2007). These data perhaps reflect the involvement of other factors in the outgrowth and in the guidance of this outgrowth, which has been suggested elsewhere (Hirata and Fujisawa, 1999), and limits previous observations which suggested that Slits would affect not only directionality but also other aspects of axonal outgrowth, like elongation and branching (Wang et al., 1999; Ma and

${ }^{1}$ This brings to relevant researchers to claim for an unidentified factor secreted by the septum (known as Pini's factor, see Figure 3) as responsible for the chemorepellent effect on $\mathrm{OB}$ axons, either alone or in concomitance with Slit-2 (Patel et al., 2001).
Tessier-Lavigne, 2007). Cues selectively involved in both axonal guidance and branching have been repeatedly described in the last years (see next epigraph).

The functional receptors of other relevant chemotropic molecules, such as the receptors for the Netrin family (DCC or Unc5H3) and those for the secreted semaphorins of the Semaphorin 3 class (Neuropilin-1 and -2), are strongly expressed by OB projection neurons and the LOT axons (Kawakami et al., 1996; Sugisaki et al., 1996; Przyborski et al., 1998; Jiménez et al., 2000; Shu et al., 2000). However, neither Netrins (secreted Netrin-1 and those anchored to cell membrane Netrin-G1) nor most of the secreted semaphorins (including the most potent chemorepellent in this class, Sema 3A) influence the outgrowth of OB axons (Kitsukawa et al., 1997; de Castro et al., 1999; Li et al., 1999; Nakashiba et al., 2000; Taniguchi et al., 2003; Kawasaki et al., 2006). The failure of the potent chemorepellent Sema 3A to affect outgrowth is reinforced by the lack of alterations to the developing LOT in the null mutant for its only known functional receptor, Neuropilin-1 (Kitsukawa et al., 1997). Nevertheless, we demonstrated that LOT axons do respond selectively to two other secreted semaphorins and indeed, Sema $3 F$ repels LOT axons and prevents them from invading the cortical plate and the ganglionic eminence, while, by contrast, Sema 3B attracts LOT 
axons and maintains them at the surface of the basal telencephalon (de Castro et al., 1999). In the same work, we proved that the olfactory epithelium secretes a chemorepellent factor for the OB axons and we suggested that Sema 3F may be responsible for this effect (de Castro et al., 1999). In addition, we revealed that the diffusible cleaved N-terminal fragment of Anosmin-1 promotes the outgrowth of and attracts $\mathrm{OB}$ axons, and this molecule is physiologically produced by the target of these $\mathrm{OB}$ axons, the olfactory cortex (Soussi-Yanicostas et al., 2002).

The secreted cues with a major role in the formation of the LOT complete Figure 3.

\section{THE COLONIZATION OF THE OLFACTORY CORTEX BY LOT AXONS: MOLECULES INVOLVED IN THE FORMATION OF AXON COLLATERALS}

Once the LOT is properly formed, these primary axons bud and generate axon collaterals that project to their target neurons within the different regions of the so-called olfactory cortex (Hirata and Fujisawa, 1999; Soussi-Yanicostas et al., 2002). Although this widespread strategy is used by growing axons to invade target areas in the developing nervous system (Kalil et al., 2000), it is the only physiological way for the $\mathrm{OB}$ mitral and tufted cells to project to specific neurons of the olfactory cortex (Hirata and Fujisawa, 1999). After a protracted waiting period (approximately 1 day) in which the primary LOT axons do not bud at all (Hirata and Fujisawa, 1999), the collaterals start to form in a precise order, following a rostro-caudal gradient in the rat (Devor, 1976; Derer et al., 1977; Scott et al., 1980; Luskin and Price, 1982; Schwob and Price, 1984; Shipley and Ennis, 1996) and a inverse caudo-rostral gradient in the mouse. Indeed, in the mouse the first LOT collaterals colonise the amygdala (at E15.5) and 1 day later, they also colonise the piriform cortex and the more rostral regions of the olfactory cortex (Hirata and Fujisawa, 1999). It is widely accepted that the same cues involved in guiding axon pathfinding could also be responsible for axon collateralization and indeed, Slit-2, a well-known chemorepellent in axon guidance seems to positively regulate sensory axonal branching (Wang et al., 1999; Hirata et al., 2001). By contrast, it has been suggested that the cues to induce collateral axon branching differ from those involved in axonal pathfinding (Hirata and Fujisawa, 1999).

Physiological cues governing branching/collateralization are still not well defined and in the case of the LOT axon collaterals, and few studies have been performed to date. For example, neither the lot1-positive cells nor the Slits (either Slit-1 or -2 alone, or in combination) seem to be involved in the collateral branching of OB mitral cells (Hirata et al., 2001; Marillat et al., 2002; Fouquet et al., 2007). However, we identified Anosmin-1 as a cue directly involved in the formation of these collaterals, a protein defective in Kallmann syndrome (syndrome: anosmia plus hypogonadotropic hypogonadism). Indeed, the role of Anosmin-1 in the formation of LOT collaterals (Soussi-Yanicostas et al., 2002) was recently corroborated by us in other projection neurons like cerebellar Purkinje cells, whose axons also bud collaterals within a very precise time frame (Gianola et al., 2009). After a protracted period of waiting, possibly to facilitate the neutralization/overriding of inhibitors of collateral sprouting (as suggested by Fujisawa's group: Sato et al., 1998), Anosmin-1 enhances axonal sprouting without affecting the growth of primary $\mathrm{OB}$ axons. Interestingly, and as stated above,
Anosmin-1 seems to contribute to the guidance of primary $\mathrm{OB}$ axons at earlier developmental stages (rat E15) but it does not trigger sprouting (Soussi-Yanicostas et al., 2002). Together with Anosmin-1, another main cue that seems to be clearly implicated in the collateralization of LOT axons is that from Sema7A (Pasterkamp et al., 2003). Significantly, although neurotrophins are promising molecules to be involved in collateral formation, they have not been shown to influence this process in the LOT (Hirata and Fujisawa, 1997). The role of both, Anosmin- 1 and Sema7A, in the formation of LOT collaterals is reflected in Figure 3.

\section{A RELATIVE BLACK HOLE: THE MOLECULAR BASIS OF THE DEVELOPMENT OF INTRACORTICAL CONNECTIONS IN THE OLFACTORY SYSTEM}

As briefly indicated above, the neurons of the olfactory cortex establish a complex pattern of synaptic connections within the olfactory cortex and with other telencephalic structures, including the OB (Figure 1). This complex connectivity makes it difficult to carry out in vitro and in vivo studies into the molecular basis of the development of the efferent projections from the olfactory cortex. Consequently, only limited studies have been devoted, either partially or entirely, to this issue, although most of them have been performed in vivo (see below).

The most studied projection from the olfactory cortex is the anterior commissure, one of the major brain commissures. The anterior commissure is divided into two pars: the anterior pars, that connects olfactory structures and the anterior PC, while the posterior pars mainly connects elements of the temporal lobe. Both pars of the anterior commissure only converge to cross midline (Pires-Neto and Lent, 1993; Cummings et al., 1997; Ho et al., 2009). The axons forming the $\mathrm{AC}$ cross the midline in close association with the ependymal layer of the third ventricle, which suggests that different molecules expressed or secreted by this germinal zone may influence the guidance of these axons. Finally, for decades the role of preformed glial pathways in the guidance of axons was considered to develop the great cerebral commissures (Silver et al., 1982), although the details on the mechanisms involved have only recently been defined.

With regards to intracellular mechanisms, COUP-TFI is of particular interest since abolishing the expression of this transcription factor (an orphan member of the steroid/thyroid hormone superfamily of nuclear receptors) produces many defects in forebrain axon guidance. Indeed, there is a significant increase in the number of anterior commissure axons crossing the midline due to the misrouting of septo-hippocampal projections, which suffer a posterior shift towards the hippocampal commissure, although the olfactory component of the anterior commissure is not thought to be affected (Armentano et al., 2006). The JNK interacting protein (JSAP1) is a scaffold protein for mitogenactivated protein kinase (MAPK) signalling pathways, as well as a linker protein for the transport of cargo along the axons. $J S A P 1^{-1-}$ mice show major disturbances in the development of telencephalic commissures, including the anterior commissure, and the transgenic JIP1 partially rescued these defects in axon guidance (Ha et al., 2005). Dramatic differences between GAP$43^{+/-}$and $G A P-43^{-/-}$mice suggest that a functional threshold of GAP-43 is required for the formation of brain commissures 
(including anterior commissure). Indeed, the failure to regulate F-actin in commissural growth cones may be related to inhibited PKC phosphorylation of GAP-43 (Shen et al., 2002).

\section{CONTACT-MEDIATED MECHANISMS INVOLVED IN THE DEVELOPMENT OF INTRACORTICAL OLFACTORY CONNECTIONS}

Studies regarding the involvement of contact-mediated mechanisms show that the loss of EphA4 produces a significant ventral and lateral displacement of the anterior pars of the anterior commissure (Ho et al., 2009), enlarging the defects previously described in this cortical tract (Dottori et al., 1998; Greferath et al., 2002). Defects in the posterior pars of the commissure also appear in this mutant strain (Kullander et al., 2001; Ho et al., 2009). Moreover, the lack of EphA4 provokes the intermingling of axons from the anterior and the posterior pars of the anterior commissure, demonstrating that the olfactory axons (anterior pars) are more sensitive to EphB2mediated repulsion than the others in this commissure (Ho et al., 2009). However, axons that are mis-projected do not sum more than $50 \%$ of the total number of axons of the anterior pars of the anterior commissure in the double EphB2/A4 knockout, which suggests that the ephrin/Eph system is not the only one involved in the formation of this structure and that it should at least be combined with secreted Sema3B (Ho et al., 2009; see below). Previously, other receptor protein-tyrosine kinases (RTKs, of which the largest subfamily is Eph-related receptor family) have been shown not to be relevant for the formation of the anterior pars of the anterior commissure, despite their involvement in the formation of other commissures in the brain, like Nuk and Sek4 (Henkemeyer et al., 1996; Orioli et al., 1996).

The expression of PSA-NCAM in different components of the olfactory cortex raised speculations about its putative role in the formation of olfactory intracortical connections (Nacher et al., 2002a,b; Bonfanti, 2006). The genetic ablation of another adhesion molecule NrCAM induces defasciculation and the aberrant ventral and lateral shift of anterior commissure axons; however, the loss of this molecule does not lead to a dramatic reduction of this commissure (Falk et al., 2005), which might reflect the secondary role of this immunoglobulin in Sema/Neuropilin signalling (see below). More dramatic effects can be seen in mutant mice in which the expression of the Celsr3 protein has been selective abolished (a member of the Cadherin family involved in cell adhesion via homophilic interactions). Thus, the anterior commissure is absent in the Celsr3 ${ }^{-/}$(Tissir et al., 2005), Celsr3/Foxg1 and Celsr3/Emx1 mice, in which diminutive bundles from olfactory nuclei grow but they never cross the midline. Hence, it is considered that Celsr3expressing guidepost cells could be found by growing Celsr $3^{+}-$ olfactory axons that cross midline and form the anterior pars of the anterior commissure (Zhou et al., 2008).

The Netrin-1 null mutant, or that of its receptor, DCC, provokes the total absence or at least a severe reduction of the anterior commissure (Serafini et al., 1996; Fazeli et al., 1997). This effect is even stronger when the expression of the multidomain GEF protein, Trio, the intermediary between Netrin-1 and Racl (Chen et al., 2007; Briançon-Marjollet et al., 2008; Kassai et al., 2008), is completely abolished. Thus, since Trio $^{+-}$mice develops an intermediate phenotype of defasciculated anterior commissure, Trio appears to be involved in both Netrin-1-induced axonal outgrowth and guidance
(Briançon-Marjollet et al., 2008). However, this phenomenon appears to be unique in the anterior commissure since the Trio ${ }^{-1-}$ phenotype in other brain commissures is milder than that of the Netrin- $1^{-1-}$ or the $D C C^{-/}$, such as in the corpus callosum or the internal capsule (Briançon-Marjollet et al., 2008).

The axons of the anterior pars of the anterior commissure also respond to the secreted class III semaphorins and their receptors, Neuropilins and Plexins. Although this commissure develops normally in Sema3 $A^{-1-}$ mice (Suto et al., 2005), its anterior pars is altered in all the Neuropilin-2 ${ }^{-1-}$, Plexin- $A 4^{--}, S e m a 3 B^{-1-}$ and Sema $3 F^{-/-}$mouse strains (Chen et al., 2000; Giger et al., 2000; Sahay et al., 2003; Falk et al., 2005; Suto et al., 2005). More specifically, the anterior pars of the anterior commissure is defasciculated and shifted ventrally in all these mutants, its number of axons is reduced in all but the Sema3B $B^{-/-}$mutant, and there is a total absence of decused axons in the PlexinA $4^{-1-}$ mice. As proposed in other structures, in the mammalian CNS there is an association of NrCAM with Neuropilin-2 in olfactory axons of the anterior commissure (the anterior pars) which is necessary for the Sema3B- and Sema3F-induced chemotropic responses, although these semaphorins never bind directly to NrCAM but to their canonical receptor Neuropilin-2. Moreover, soluble NrCAM does not antagonize semaphorin binding to Neuropilin-2 or its combination with Plexin-A (Falk et al., 2005). It also seems remarkable that the attraction of the axons of the anterior pars of the anterior commissure to Sema3B is especially relevant, because a single allele mutation has a phenotype as strong as the heterozygous mutant of the receptor, Neuropilin ${ }^{+-}$(Falk et al., 2005). From this scenario, it can be concluded that in the development of the olfactory anterior pars of the anterior commissure:

(i) the secreted class III semaphorins studied to date (Sema3A, Sema3B and Sema3F) are not redundant but rather, they play distinct roles that can not be compensated for, reflecting their different functional properties and corresponding to the expression of each of these proteins;

(ii) both Neuropilin-2 and PlexinA4, but not Neuropilin-1, are the functional receptors for secreted semaphorins in the axons of the anterior pars of the anterior commissure, and they can both form receptor complexes for Sema3F;

(iii) the spatial coordinates of the olfactory cortex tract are probably be determined by the amount of ligand/receptor interactions.

Interestingly, these mechanisms reflect a certain degree of conservation between different CNS projection systems: Sema3B and Sema3F control the guidance of commissural axons at the spinal cord midline, where NrCAM also plays a critical role in crossing decisions (Stoeckli and Landmesser, 1998; Zou et al., 2000).

While studying the role of Slits and their Robo receptors in the formation of the LOT (see above), some axons from the OB are misrouted in the double null Slit $1^{-1-}$; Slit $2^{-/-}$mutant, crossing to the contralateral hemisphere and maybe thickening the ACa (Fouquet et al., 2007). These effects are not observed in the Slit $1^{+-}$; Slit2 $2^{-1-}$ animals, or in the corresponding single mutants (N'Guyen-Ba-Charvet et al., 2002; Fouquet et al., 2007). The exact role of Slits in the formation of forebrain commissures (including anterior commissure) 
remains to be clearly defined, and based on the results obtained in zebrafish, Slits would fulfil a role that could be regulated by $\mathrm{Hh}$ signalling (Barresi et al., 2005).

In the scenario of the dramatic defects in most of the major fibre tracts in the brain, null mutation of the Frizzled-3 gene produces the complete absence of the anterior commissure (Wang et al., 2002, 2006). However, this phenotype is so severe that the true extent of the role of Wnt/Frizzled signalling in the formation of intracortical olfactory connections remains to be studied.

All these findings have recently been reinforced by the interesting finding that the same chemotropic molecules that are relevant for the development of the forebrain commissures in rodents have been also seen in the human (Ren et al., 2006).

\section{CELLULAR AND MOLECULAR MECHANISMS WIRING THE ACCESSORY OLFACTORY SYSTEM}

In most terrestrial vertebrates, the accessory olfactory system (Figure 1) is the second anatomically distinct chemosensory system involved in olfactory perception. Indeed, in parallel to the main olfactory system, the accessory olfactory system detects pheromones (Halpern, 1987; Buck, 2000; Mombaerts, 2001; Dulac and Torello, 2003). Thus, to complete this review we will resume the few studies devoted to this issue in the accessory olfactory system.

With regards cell surface molecules involved in the formation of this system, it has been suggested that different carbohydrates, like lectins, could be involved in the targeting of OSNs to the AOB (Lipscomb et al., 2003). Reelin is expressed in different structures of the olfactory system, including the perineural cells near the vomeronasal nerve, the vomeronasal organ and in the AOB. However, the vomeronasal nerves are absolutely normal in the reeler mutant mice, which strongly suggests that Reelin does not provide a guidance cue for vomeronasal axons (Teillon et al., 2003), as occurs in the olfactory nerve (see above). As in the case of the main olfactory system (see above), PSA-NCAM has been suggested to be involved in the formation of the connectivity between the different components of the accessory olfactory system (Nacher et al., 2002b; Bonfanti, 2006).

A detailed study of the role of secreted molecules in the formation of this projection indicated that Sema $3 \mathrm{~F}$ plays a minor role in targeting the axons of the apical vomeronasal neurons to their proper lamina-specific site in the AOB (Cloutier et al., 2004), confirming previous data along these lines (Cloutier et al., 2002; Walz et al., 2002). Finally, although it has been shown that Slit-1 repels vomeronasal axons in vitro (Knöll et al., 2003), the in vivo scenario shows that while Slit-1 is dispensable for the guidance and fasciculation of the axons of the vomeronasal neurons, it is critical for the correct targeting of these afferents towards the posterior AOB (Cloutier et al., 2004).

\section{DISCUSSION}

In this essay, we have presented the full scenario of molecular mechanisms involved in the formation of different connections within the olfactory system during development: the olfactory nerve, the LOT and the intra-cortical connections, as well as a brief summary of the mechanisms studied in the vomero-nasal nerve. We can conclude that the expectations raised by the mechanisms that we have considered as "special mechanisms" (the olfactory receptors for the olfactory nerve, and the lot $1^{+}$-cells for the LOT) have become somewhat tarnished with the progress made in the field. Regarding the cues involved in the outgrowth and guidance of different axonal populations of the olfactory system, the scenario reflects what has been seen in other parts of the CNS, including the cooperation between both attractive and repulsive signals, as well as the existence of a hierarchy among these signals (Stein and Tessier-Lavigne, 2001); in the case of both the neurogenesis of mitral cells in the OB and for the initiation of LOT formation, the top of this hierarchy would be represented by the critical role of Tbr-1 (Bulfone et al., 1998). In reference to the described cooperation among different cues, in the olfactory system it has been proven the interaction of secreted molecules with non-diffusible components of the extracellular matrix, giving rise to important functional implications for the establishment of the correct synaptic connectivity during development (Sugisaki et al., 1996; Soussi-Yanicostas et al., 2002). But the olfactory system shows at least two singularities regarding the molecular orchestration of axonal pathfinding:

(i) the cues that do not seem to be useful for guiding OB mitral cell axons or intracortical projections, seem relevant for the growth of OSN axons, and/or vice versa (e.g. Sema 3A, Netrin-1; Table 1);

(ii) the weak heterogeneity of the LOT when compared to the $\mathrm{ON}$ is likely to be the cause that contact-mediated mechanisms contribute less to the formation of the LOT than of the ON (Potter et al., 2001; Treloar et al., 2002).

All these would reflect the particularity of the first synapsis of the system. These exceptional neruons, in physical contact with the exterior medium (either water or air), the OSNs die and are replaced by contingents of newly generated neurons which, at their turn, are capable to afford fast axonal growth to establish proper new connections with their corresponding glomeruli within the OB (Brodal, 2004). With a natural life of approximately 90 days before they die and being replaced by new OSNs born from the stem cells of the olfactory epithelium, this is a massive example of neurogenesis maintained in the mature and in the adult mammals which does not differs in numbers of what happens in embryonic and early postnatal development (Graziadei and Monti-Graziadei, 1980). In this fascinating scenario for modern developmental neurobiologists, it has been suggested that the cues that guide OSN axons to form their synapses within the $\mathrm{OB}$ are, in grosso modo, preserved throughout the life of the animal (Gogos et al., 2000; Potter et al., 2001), and experimental evidences strongly suggest that OSN axons project to the $\mathrm{OB}$ without a direct influence of target-derived cues produced by the latter, whose effects should be confined for the final local scenario (Graziadei and Monti Graziadei, 1986; LópezMascaraque and de Castro, 2002, 2004; Chehrehasa et al., 2006; Schwarting and Henion, 2008). This is totally different from which is observed in the visual system, for example, in which retinal axons need from molecular gradients produced by the target to form the map of projections (Feldheim et al., 2000; Mann et al., 2002). All these properties of OSNs would explain the fast replacing of cell and the development of their exact connectivity in a mature system, which results in a maintained function without significant changes in olfactory perception: although olfaction is frequently considered 
as a kind of luxury for humans (species in which seems uniquely flexible to acquire food preferences and influence in other aspects of complex behaviour), the detection of chemicals in environment is crticial for survival and life, in ageneral sense, from bacteria to mammals (Firestein, 2001; Elsaesser and Paysan, 2007).

It is remarkable that maintained neurogenesis in the olfactory epithelium is not the only one in the olfactory system, because precursors of future $\mathrm{OB}$ interneurons are continuously generated in the neurogenic niche of the forebrain subventricular zone since the embryonic development till adulthood, forming the rostral migratory stream between the neurogenic niche and the final target of these cells, the OB (Hinds, 1968; Bayer, 1983; Luskin, 1993; Lois and Álvarez-Buylla, 1994; Marín and Rubenstein, 2003). This means that both newly-generated neurons integrate continuously in mature OBs: every newly-born OSNs must connect its target glomeruli in the very precise pattern that is known while the newly-arrived OB interneurons must develop their new connections, and vice versa (Belluzzi et al., 2003). It is difficult to find another structure within the CNS which shows such a degree of physiological plasticity. The only limit to this olfactory perpetuum mobile seems to be the fact that the sequence of physiological maturation of the OSN synapses onto the $\mathrm{OB}$ glomeruli is almost identical during postnatal development and in the adulthood (Grubb et al., 2008), because the physiological maturation of OB interneurons differs as much in the postnatal development from the situation in the adult as these newly-generated neurons do in their final destination within the OB (Carleton et al., 2003; Lemasson et al., 2005; recently reviewed in Lledó et al., 2008). In this sense, it has been concluded that while the newly-arrived interneurons can provide different physiological messages while they integrate and mature in the $\mathrm{OB}$, the OSNs assure reliable inputs to the $\mathrm{OB}$ independently of the moment in which they are generated and their terminals synapt with their targets (Grubb et al., 2008). On the contrary, a balanced equilibrium between the death of interneurons in the OB the arrival of newly-generated interneurons is necessary to assure an optimal olfactory function (Mouret et al., 2009). It results intringuing that both types of maintained neurogenesis respond to different controls: while odor exposure and sensory experience regulates the neurogenesis in the SVZ/RMS and the survival and maturation of these newly-generated interneurons (Petreanu and Álvarez-Buylla, 2002; Rochefort et al., 2002; Yamaguchi and Mori, 2005; Alonso et al., 2006; Mandairon et al., 2006; Mouret et al., 2008), it seems that olfactory epithelium neurogenesis is locally controlled by the balance of one member of the transforming growth factor- $\beta$ family, growth and differentiation factor-11 and its antagonist follistatin (Wu et al., 2003).

All these OSN peculiarities would reflect the evolutionary relevance of the sense of smell in the development of the CNS. Smell is the most primitive sense, and most if not all the cerebrum is devoted to it in the ealy phylogenetical stages of vertebrates, prevalence that decreases as the neocortex and the other sensorial functions appear in phylogenia (Brodal, 2004). Their exceptional condition as "primitive" neurons renders OSNs with exceptional biological capabilities, for example (Brodal, 2004):

(i) they die and are actively replaced during all the life;

(ii) their axons directly project to a first telencephalic station (the $\mathrm{OB}$ ) instead to use the thalamus as first relay; (iii) the unmyelinated axons of the OSNs are protected by a very special type of glia generated, as these neurons, in the olfactory placode (the olfactory ensheating glia).

The importance of the facial mesenchyme in the development of the olfactory placode and its derivatives must not be forgotten (Szabo-Rogers et al., 2009).

The particular characteristics of OSNs, together with the idea that the $\mathrm{OB}$ represents a developmental independent domain (López-Mascaraque and de Castro, 2002), support the existence of a protomap for the initial development of the olfactory system, from which three major components must be identified: the olfactory epithelium, OB and olfactory cortex. The differences in the molecular orchestraes underlying the formation of the tracts interconnecting the olfactory structures (see above) would also be interpreted as a support for the protomap theory (see Introduction: A Brief Sketch of the Olfactory System and its Development). This protomap is important during development, although recent reports have questioned if it is also applicable to the mature olfactory system, where it is now believed that olfactory nerve inputs to the $\mathrm{OB}$ are sparse (like the connections between projection neurons from the $\mathrm{OB}$ and their targets in the olfactory cortex) with no functional map (Fantana et al., 2008; Geffen et al., 2009; Soucy et al., 2009).

Another point that merits detailed discussion is the role of activity in the formation of the synaptic connections between the different structures of the olfactory system. To date, the activity of neurons has been demonstrated to play an important role in the morphogenesis of the olfactory nerve, concretely, in the final refinement of their connections within the OB (Trinh and Storm, 2003; Yu et al., 2004; Zou et al., 2004; Mombaerts, 2006; Chesler et al., 2007; Dal Col et al., 2007), although it would be also relevant for the development of the LOT and for the intracortical connections, and also for the accessory olfactory system. The activitydependency of the projections from the olfactory epithelium to the $\mathrm{OB}$ could also provide functional correlates for the demonstrated role of olfactory activity in the survival of newly-generated interneuron precursors which migrate to the $\mathrm{OB}$ (Rochefort et al., 2002; Alonso et al., 2006, 2008; Mandairon et al., 2006). The effects of sensorial activity in the plasticity of the olfactory system have been discussed above.

In despite of its origin and clear influences in the formation of the main olfactory system (i.e.: the influence of AOB axons in the organization of the LOT), as well as of the recent research regarding types of vomeronasal receptors and the organization of the vomeronasal cortex (reviewed in Martínez-Marcos, 2009), the main conclusion that we can extract from the studies published to date is that the molecular mechanisms involved in the development of the connectivity in the accessory olfactory system are far from being ellucidated.

Finally, it should be highlighted the increasingly relevance of the molecules reviewed in the present work for Neurological pathology (de Castro, 2001; Sarnat and Flores-Sarnat, 2001; Sarnat, 2007). Their impact in pathologies which affect the olfactory system remains to be elucidated, with the exception of Anosmin-1 and FGFs, which seems clear that plays a major functional role in Kallmann syndrome (Dodé and Hardelin, 2009). 


\section{ACKNOWLEDGMENTS}

I am indebted to Prof. Fernando Martínez-Gacía, Dr Javier Arenzana and Diego García-González for their comments and suggestions on the manuscript and for their technical support and help in the final editing of this work. This work was supported by grants

\section{REFERENCES}

Akins, M. R., Benson, D. L., and Greer, C. A. (2007). Cadherin expression in the developing mouse olfactory system. J. Comp. Neurol. 501, 483-497.

Akins, M.R., and Greer, C.A. (2006). Axon behavior in the olfactory nerve reflects the involvement of catenin-cadherin mediated adhesion. J. Comp. Neurol. 499, 979-989.

Alenius, M., and Bohm, S. (2003). Differential function of RNCAM isoforms in precise target selection of olfactory sensory neurons. Development 130, 917-927.

Alonso, M., Ortega-Pérez, I., Grubb, M. S., Bourgeois, J. P., Charneau, P., and Lledó, P. M. (2008). Turning astrocytes from the rostral migratory stream into neurons: a role for the olfactory sensory organ. J. Neurosci. 28, 11089-11102.

Alonso, M., Viollet, C., Gabellec, M. M., Meas-Yedid, V., Olivo-Marín, J. C., and Lledó, P. M. (2006). Olfactory discrimination learning increases the survival of adult-born neurons in the olfactory bulb. J. Neurosci. 26, 10508-10513.

Aoki, K., Ankara, Y., Yamada, S., and Eto, K. (1999). Role of polysialic acid on outgrowth of rat olfactory receptor neurons. Mech. Dev. 85, 103-110.

Ardiles, Y., de la Puente, R., Toledo, R., Isgor, C., and Guthrie, K. (2007). Response of olfactory axons to loss of synaptic targets in the adult mouse. Exp. Neurol. 207, 275-288.

Armentano, M., Filosa, A., Andolfi, G., and Studer, M. (2006). COUP-TFI is required for the formation of commissural projections in the forebrain by regulating axonal growth. Development 133, 4151-4162.

Astic, L., Pellier-Monnin, V., Saucier, D., Charrier, C., and Mehlen, P. (2002). Expression of netrin-1 and netrin-1 receptor, DCC, in the rat olfactory nerve pathway during development and axonal regeneration. Neuroscience 109, 643-656.

Baker, H., Cummings, D. M., Munger, S. D., Margolis, J. W., Franzen, L., Reed, R. R., and Margolis, F. L. (1999). Targeted deletion of a cyclic nucleotide-gated channel subunit (OCNC1): biochemical and morphological consequences in adult mice. J. Neurosci. 19, 9313-9321.

Barnea, G., O’Donnell, S., Mancia, F., Sun, X., Nemes, A., Mendelsohn, M., and
Axel, R. (2004). Odorant receptors 304, 1468.

Barresi, M. J., Hutson, L. D., Chien, C. B., and Karlstrom, R. O. (2005). Hedgehog regulated Slit expression determines commissure and glial cell position in the zebrafish forebrain. Development 132, 3643-3656.

Bayer, S. A. (1983). 3H-thymidineradiographic studies of neurogenesis in the rat olfactory bulb. Exp. Brain Res. 50, 329-340.

Belluscio, L., Gold, G. H., Nemes, A., and Axel, R. (1998). Mice deficient in G(olf) are anosmic. Neuron 20, 69-81.

Belluzzi, O., Benedusi, M., Ackman, J., and LoTurco, J. J. (2003). Electrophysiological differentiation of new neurons in the olfactory bulb. J. Neurosci. 23, 10411-10418. and Fadool, D. A. (2008). Deletion of voltage-gated channel affects glomerular refinement and odorant receptor expression in the mouse olfactory system. J. Comp. Neurol. 506, 161-179.

Blanchart, A., De Carlos, J.A., and LópezMascaraque, L. (2006). Time frame of mitral cell development in the mice olfactory bulb. J. Comp. Neurol. 496, 529-543.

Bonfanti, L. (2006). PSA-NCAM in mammalian structural plasticity and neurogenesis. Prog. Neurobiol. 80, 129-164.

Briançon-Marjollet, A., Ghogha, A., Nawabi, H., Triki, I., Auziol, C., Fromont, S., Piché, C., Enslen, H., Chebli, K., Cloutier, J. F., Castellani, V., Debant, A., and Lamarche-Vane, N. (2008). Trio mediates netrin-1induced Racl activation in axon outgrowth and guidance. Mol. Cell. Biol. 28, 2314-2323.

Brodal, P. (2004). The Central Nervous System: Structure and Function. Oxford, Oxford University Press.

Buck, L., and Axel, R. (1991). A novel multigene family may encode odorant receptors: a molecular basis for odor recognition. Cell 65, 175-187.

Buck, L. B. (2000). The molecular architecture of odor and pheromone sensing in mammals. Cell 100, 611-618.

Bulfone,A., Wang, F., Hevner, R.,Anderson, S., Cutforth, T., Chen, S., Meneses, J., Pedersen, R., Axel, R., and Rubenstein, J. L. (1998). An olfactory sensory map develops in the absence of normal on axon termini in the brain. Science

Biju, K. C., Marks, D. R., Mast, T. G.,

SAF2007-65845 (MICINN), PI2007-66 (FISCAM), G-2008-C8 (FISCAM) and ICS06024-00 (Consejería de Sanidad de la Junta de Comunidades de Castilla-La Mancha), and both FUHNPAIIN and SESCAM generously support different aspects of our research group's activities.

projection neurons or GABAergic interneurons. Neuron 21, 1273-1282.

Cajal, S. R. (1890). Origen y terminación de las fibras nerviosas olfatorias. Gac. San. Barcelona. 3, 133-139, 174-181, 206-212.

Carleton, A., Petreanu, L. T., Lansford, R., Álvarez-Buylla, A., and Lledó, P. M. (2003). Becoming a new neuron in the adult olfactory bulb. Nat. Neurosci. 6 , 507-518.

Carson, C., Saleh, M., Fung, F. W. Nicholson, D. W., and Roskams, A. J. (2005). Axonal dynactin p150Glued transports caspase- 8 to drive retrograde olfactory receptor neuron apoptosis. J. Neurosci. 25, 6092-6104.

Caviness, V.S. Jr., and Sidman, R. L. (1972). Olfactory structures of the forebrain in the reeler mutant mouse. J. Comp. Neurol. 145, 85-104.

Chehrehasa, F., St John, J. A., and Key, B. (2006). Implantation of a scaffold following bulbectomy induces laminar organization of regenerating olfactory axons. Brain Res. 1119, 58-64.

Chen, Y., and Flanagan, J. G. (2006) Follow your nose: axon pathfinding in olfactory map formation. Cell 127 , 881-884.

Chen, H., Bagri, A., Zupicich, J. A., Zou, Y. Stoeckli, E., Pleasure, S. J., Lowenstein, D. H., Skarnes, W. C., Chédotal, A., and Tessier-Lavigne, M. (2000). Neuropilin-2 regulates the development of selective cranial and sensory nerves and hippocampal mossy fiber projections. Neuron 25, 43-56.

Chen, L., Liao, G., Waclaw, R. R., Burns, K. A., Linquist, D., Campbell, K., Zheng, Y., and Kuan, C. Y. (2007). Racl controls the formation of midline commissures and the competency of tangential migration in ventral telencephalic neurons. J. Neurosci. 27, 3884-3893.

Chesler, A. T., Zou, D. J., Le Pichon, C. E. Peterlin, Z.A., Matthews, G.A., Pei, X., Miller, M. C., and Firestein, S. (2007). A G protein/cAMP signal cascade is required for axonal convergence into olfactory glomeruli. Proc. Natl. Acad. Sci. U.S.A. 104, 1039-1044.

Cho, H., Lépine, M., Andrews, W., Parnavelas, J., and Cloutier, J. F. (2007). Requirement for Slit-1 and Robo-2 in zonal segregation of olfactory sensory neuron axons in the main olfactory bulb. J. Neurosci. 27 , 9094-9104.
Cloutier, J. F., Giger, R. J., Koentges, G. Dulac, C., Kolodkin, A. L., and Ginty, D. D. (2002). Neuropilin-2 mediates axonal fasciculation, zonal segregation, but not axonal convergence, of primary accessory olfactory neurons. Neuron 33, 877-892.

Cloutier, J. F., Sahay, A., Chang, E. C., Tessier-Lavigne, M., Dulac, C., Kolodkin, A. L., and Ginty, D. D. (2004). Differential requirements for semaphorin $3 \mathrm{~F}$ and Slit-1 in axonal targeting, fasciculation, and segregation of olfactory sensory neuron projections. J. Neurosci. 24, 9087-9096.

Colón-Ramos, D. A., and Shen, K. (2008). Cellular conductors: glial cells as guideposts during neural circuit development. PLoS Biol. 6, e112. doi: 10.1371/journal.pbio.0060112.

Conzelmann, S., Malun, D., Breer, H., and Strotmann, J. (2001). Brain targeting and glomerulus formation of two olfactory neuron populations expressing related receptor types. Eur. J. Neurosci. 14, 1623-1632.

Costanzo, R. M. (2000). Rewiring the olfactory bulb: changes in odor maps following recovery from nerve transection. Chem. Senses 25, 199-205.

Cummings, D. M., Malun, D., and Brunjes, P. C. (1997). Development of the anterior commissure in the opossum: midline extracellular space and glia coincide with early axon decussation. J. Neurobiol. 32, 403-414

Cutforth, T., Moring, L., Mendelsohn, M., Nemes, A., Shah, N. M., Kim M. M., Frisén, J., and Axel, R. (2003). Axonal ephrin-As and odorant receptors: coordinate determination of the olfactory sensory map. Cell 114, 311-322.

Dal Col, J. A., Matsuo, T., Storm, D. R., and Rodriguez, I. (2007). Adenylyl cyclase-dependent axonal targeting in the olfactory system. Development 134, 2481-2489.

de Castro, F. (2001). Moléculas quimiotrópicas como mecanismo de orientación del crecimiento axonal y de la migración neuronal durante el desarrollo del sistema nervioso de los mamíferos. Rev. Neurol. 33, 54-68.

de Castro, F., Hu, L., Drabkin, H., Sotelo, C., and Chédotal, A. (1999). Chemoattraction and chemorepulsion of olfactory bulb axons by different secreted semaphorins. J. Neurosci. $19,4428-4436$. 
Derer, P., Caviness, V.S. Jr., and Sidman, R. L. (1977). Early cortical histogenesis in the primary olfactory cortex of the mouse. Brain Res. 123, 27-40.

Devor, M. (1976). Fiber trajectories of olfactory bulb efferents in the hamster. J. Comp. Neurol. 166, 31-48.

Dodé, C., and Hardelin, J. P. (2009). Kallmann syndrome. Eur. J. Hum. Genet. 17, 139-146.

Dottori,M.,Hartley,L., Galea, M., Paxinos, G., Polizzotto, M., Kilpatrick, T., Bartlett, P. F., Murphy, M., Köntgen, F., and Boyd, A.W. (1998). EphA4 (Sek1) receptor tyrosine kinase is required for the development of the corticospinal tract. Proc. Natl. Acad. Sci. U.S.A. 95, 13248-13253.

Doucette, R. (1989). Development of the nerve fiber layer in the olfactory bulb of mouse embryos. J. Comp. Neurol. 285, 514-527.

Dulac, C., and Torello, A. T. (2003). Molecular detection of pheromone signals in mammals: from genes to behaviour. Nat. Rev. Neurosci. 7, 551-562.

Elsaesser, R., and Paysan, J. (2007). The sense of smell, its signalling pathways, and the dichotomy of cilia and microvilli in olfactory sensory cells. BMC Neurosci. 8, S1.

Falk, J., Bechara, A., Fiore, R., Nawabi, H., Zhou, H., Hoyo-Becerra, C., Bozon, M., Rougon, G., Grumet, M., Püschel, A. W., Sanes, J. R., and Castellani, V. (2005). Dual functional activity of semaphorin $3 \mathrm{~B}$ is required for positioning the anterior commissure. Neuron 48, 63-75.

Fantana, A. L., Soucy, E. R., and Meister, M. (2008). Rat olfactory bulb mitral cells receive sparse glomerular inputs. Neuron 59, 802-814.

Fazeli, A., Dickinson, S. L., Hermiston, M. L., Tighe, R. V., Steen, R. G., Small, C. G., Stoeckli, E. T., Keino-Masu, K., Masu, M., Rayburn, H., Simons, J., Bronson, R. T., Gordon, J. I., Tessier-Lavigne, M., and Weinberg, R. A. (1997). Phenotype of mice lacking functional deleted in colorectal cancer (Dcc) gene. Nature 386, 796-804.

Feinstein, P., Bozza, T., Rodriguez, I., Vassalli,A., and Mombaerts, P. (2004). Axon guidance of mouse olfactory sensory neurons by odorant receptors and the beta2 adrenergic receptor. Cell $117,833-846$.

Feinstein, P., and Mombaerts, P. (2004). A contextual model for axonal sorting into glomeruli in the mouse olfactory system. Cell 117, 817-831.

Feldheim, D. A., Kim, Y. I., Bergemann, A. D., Frisén, J., Barbacid, M., and Flanagan, J. G. (2000). Genetic analysis of ephrin-A2 and ephrin-A 5 shows their requirement in multiple aspects of retinocollicular mapping. Neuron $25,563-574$

Firestein, S. (2001). How the olfactory system makes sense of scents. Nature 413, 211-218.

Fleischmann, A., Shykind, B. M., Sosulski, D. L., Franks, K. M., Glinka, M. E., Mei D. F., Sun, Y., Kirkland, J., Mendelsohn, M., Albers, M. W., and Axel, R. (2008). Mice with a "monoclonal nose": perturbations in an olfactory map impair odor discrimination. Neuron 60, 1068-1681.

Fouquet, C., Di Meglio, T., Ma, L., Kawasaki, T., Long, H., Hirata, T., Tessier-Lavigne, M., Chédotal, A., and N'Guyen-Ba-Charvet, K. T. (2007). Robol and robo 2 control the development of the lateral olfactory tract. J. Neurosci. 27, 3037-3045.

Fukuchi-Shimogori, T., and Grove, E. A. (2001). Neocortex patterning by the secreted signaling molecule FGF8. Science 294, 1071-1074.

Geffen, M. N., Broome, B. M., Laurent, G., and Meister, M. (2009). Neural encoding of rapidly fluctuating odors. Neuron 61, 570-586.

Giacobini, P., Messina, A., Wray, S. Giampietro, C., Crepaldi, T., Carmeliet, P., and Fasolo, A. (2007). Hepatocyte growth factor acts as a motogen and guidance signal for gonadotropin hormone-releasing hormone-1 neuronal migration. J. Neurosci. 27, 431-445.

Gianola, S., de Castro, F., and Rossi, F. (2009). Anosmin-1 stimulates outgrowth and branching of developing Purkinje axons. Neuroscience 158, 570-584.

Giger, R. J., Cloutier, J. F., Sahay, A. Prinjha, R. K., Levengood, D. V., Moore, S. E., Pickering, S., Simmons, D., Rastan, S., Walsh, F. S., Kolodkin, A. L., Ginty, D. D., and Geppert, M. (2000). Neuropilin-2 is required in vivo for selective axon guidance responses to secreted semaphorins. Neuron 25, 29-41.

Gogos, J. A., Osborne, J., Nemes, A., Mendelsohn, M., and Axel, R. (2000). Genetic ablation and restoration of the olfactory topographic map. Cell 103, 609-620.

Goldman, S. A., and Luskin, M. B. (1998). Strategies utilized by migrating neurons of the postnatal vertebrate forebrain. Trends Neurosci. 21, 107-114.

Gong, Q., and Shipley, M. T. (1996). Expression of extracellular matrix molecules and cell surface molecules in the olfactory nerve pathway during early development. J. Comp. Neurol. 366, 1-14.

Graziadei, P. P., and Monti-Graziadei, G. A. (1980). Neurogenesis and neuron regeneration in the olfactory system of mammals. III. Deafferentation and reinnervation of the olfactory bulb following section of the fila olfactoria in rat. J. Neurocytol. 9, 145-162.

Graziadei, P.P., and Monti Graziadei, G.A (1986). Neuronal changes in the forebrain of mice following penetration by regenerating olfactory axons. J. Comp. Neurol. 247, 344-356.

Greer, C. A. (1991). Structural organization of the olfactory system. In Smel and Taste in Health and Disease, T.V. Getchell, R.L. Doty, L.M. Bartoshuk and J.B. Snow Jr., eds (New York, Raven), pp. 65-81.

Greferath, U., Canty,A. J. Messenger, J., and Murphy, M. (2002). Developmenta expression of EphA4-tyrosine kinase receptor in the mouse brain and spinal cord. Mech. Dev. 119, S231-S238.

Grubb, M. S., Nissant, A., Murray, K., and Lledó, P. M. (2008). Functional maturation of the first synapse in olfaction development and adult neurogenesis. J. Neurosci. 28, 2919-2932.

Ha, H. Y., Cho, I. H., Lee, K. W., Lee, K. W., Song, J. Y., Kim, K. S., Yu, Y. M. Lee, J. K., Song, J. S., Yang, S. D., Shin, H. S., and Han, P. L. (2005). The axon guidance defect of the telencephalic commissures of the JSAP1-deficient brain was partially rescued by the transgenic expression of JIP1. Dev. Biol. 277, 184-199.

Halpern, M. (1987). The organization and function of the vomeronasal system. Annu. Rev. Neurosci. 10, 325-362.

Henion, T. R., and Schwarting, G. A (2007). Patterning the developing and regenerating olfactory system. J. Cell. Physiol. 210, 290-297.

Henion, T. R., Raitcheva, D., Grosholz, R., Biellmann, F., Skarnes, W. C., Hennet, T., and Schwarting, G. A (2005). Beta1,3-N-acetylglucosaminyltransferase 1 glycosylation is required for axon pathfinding by olfactory sensory neurons. $J$. Neurosci. 25, 1894-1903.

Henkemeyer, M., Orioli, D., Henderson, J. T., Saxton, T. M., Roder, J., Pawson, T., and Klein, R. (1996). Nuk controls pathfinding of commissural axons in the mammalian central nervous system. Cell 86, 35-46.

Heyden, A., Angenstein, F., Sallaz, M. Seidenbecher, C., and Montag, D. (2008). Abnormal axonal guidance and brain anatomy in mouse mutants for the cell recognition molecules close homolog of L1 and NgCAM-related cell adhesion molecule. Neuroscience 155, 221-233.

Hinds, J. W. (1968). Autoradiographic study of histogenesis in the mouse olfactory bulb. II. Cell proliferation and migration. J. Comp. Neurol. 134 305-322.

Hirata, T., and Fujisawa, H. (1997). Cortexspecific distribution of membranebound factors that promote neurite outgrowth of mitral cells in culture. J. Neurobiol. 32, 415-425.

Hirata, T., and Fujisawa, H. (1999). Environmental control of collateral branching and target invasion of mitral cell axons during development. J. Neurobiol. 38, 93-104.

Hirata, T., Fujisawa, H., Wu, J. Y., and Rao, Y. (2001). Short-range guidance of olfactory bulb axons is independent of repulsive factor slit. J. Neurosci. 21, 2373-2379.

Ho, S. K., Kovacević, N., Henkelman, R. M., Boyd, A., Pawson, T., and Henderson, J. T. (2009). EphB2 and EphA4 receptors regulate formation of the principal inter-hemispheric tracts of the mammalian forebrain. Neuroscience 160, 784-795.

Holmberg, J., and Frisén, J. (2002). Ephrins are not only unattractive. Trends Neurosci. 25, 239-243.

Imai, T., and Sakano, H. (2008). Interhemispheric olfactory circuit and the memory beyond. Neuron 58 , 465-467.

Imai, T., Suzuki, M., and Sakano, H. (2006). Odorant receptor-derived cAMP signals direct axonal targeting. Science 314, 657-661.

Inaki, K., Nishimura, S., Nakashiba, T., Itohara, S., and Yoshihara, Y. (2004). Laminar organization of the developing lateral olfactory tract revealed by differential expression of cell recognition molecules. J. Comp. Neurol. 479, 243-256.

Ito, K., Kawasaki, T., Takashima, S. Matsuda, I., Aiba, A., and Hirata T. (2008). Semaphorin 3F confines ventral tangential migration of lateral olfactory tract neurons onto the telencephalon surface. J. Neurosci. 28, 4414-4422.

Iwema, C. L., and Schwob, J. E. (2003). Odorant receptor expression as a function of neuronal maturity in the adult rodent olfactory system. J. Comp. Neurol. 459, 209-222.

Jhaveri, D., Saharan, S., Sen, A., and Rodrigues, V. (2003). Positioning sensory terminals in the olfactory lobe of Drosophila by Robo signalling. Development 131, 1903-1912.

Jiménez, D., García, C., de Castro, F., Chédotal,A., Sotelo, C., De Carlos, J.A., Valverde, F., and López-Mascaraque, L. (2000). Evidence for intrinsic development of olfactory structures in Pax-6 mutant mice. J. Comp. Neurol. 428, 511-526.

Kalil, K., Szebenyi, G., and Dent, E. W. (2000). Common mechanisms underlying growth cone guidance and axon branching. J. Neurobiol. 44, 145-158.

Kaneko-Goto, T., Yoshihara, S., Miyazaki, H., and Yoshihara, Y. (2008). BIG-2 mediates olfactory axon convergence 
to target glomeruli. Neuron 57, 834-846.

Kassai, H., Terashima, T., Fukaya, M., Nakao, K., Sakahara, M., Watanabe, M., and Aiba, A. (2008). Racl in cortical projection neurons is selectively required for midline crossing of commissural axonal formation. Eur. J. Neurosci. 28, 257-267.

Kawakami,A., Kitsukawa, T., Takagi,S., and Fujisawa, H. (1996). Developmentally regulated expression of a cell surface protein neuropilin in the mouse nervous system. J. Neurobiol. 29, 1-17.

Kawasaki, T., Ito, K., and Hirata, T. (2006). Netrin 1 regulates ventral tangential migration of guidepost neurons in the lateral olfactory tract. Development 133, 845-853.

Kitsukawa, T., Shimizu, M., Sanbo, M., Hirata, T., Taniguchi, M., Bekku, Y., Yagi, T., and Fujisawa, H. (1997). Neuropilinsemaphorin III/D-mediated chemorepulsive signals play a crucial role in peripheral nerve projection in mice. Neuron 19, 995-1005.

Knöll, B., Schmidt, H., Andrews, W., Guthrie, S., Pini, A., Sundaresan, V., and Drescher, U. (2003). On the topographic targeting of basal vomeronasal axons through Slit-mediated chemorepulsion. Development 130, 5073-5082.

Kullander, K., Mather, N. K., Diella, F., Dottori, M., Boyd, A. W., and Klein, R. (2001). Kinase-dependent and kinaseindependent functions of EphA4 receptors in major axon tract formation in vivo. Neuron 29, 73-84.

Lee, W., Cheng, T.W., and Gong, Q. (2008). Olfactory sensory neuron-specific and sexually dimorphic expression of protocadherin 20. J. Comp. Neurol. 507, 1076-1086.

Lemasson, M., Saghatelyan, A., OlivoMarín, J. C., and Lledó, P. M. (2005). Neonatal and adult neurogenesis provide two distinct populations of newborn neurons to the mouse olfactory bulb. J. Neurosci. 25, 6816-6825.

Li, H. S., Chen, J. H., Wu, W., Fagaly, T., Zhou, L., Yuan, W., Dupuis, S., Jiang, Z. H., Nash, W., Gick, C., Ornitz, D. M., Wu, J. Y., and Rao, Y. (1999). Vertebrate slit, a secreted ligand for the transmembrane protein roundabout, is a repellent for olfactory bulb axons. Cell 96, 807-818.

Li, M., and Ransohoff, R. M. (2008). Multiple roles of chemokine CXCL12 in the central nervous system: a migration from immunology to neurobiology. Prog. Neurobiol. 84, 116-131.

Lin, D. M., Wang, F., Lowe, G., Gold, G. H., Axel, R., Ngai, J., and Brunet, L. (2000). Formation of precise connections in the olfactory bulb occurs in the absence of odorant-evoked neuronal activity. Neuron 26, 69-80.
Lipscomb, B. W., Treloar, H. B., Klenoff, J., and Greer, C. A. (2003). Cell surface carbohydrates and glomerular targeting of olfactory sensory neuron axons in the mouse. J. Comp. Neurol. 467, 22-31.

Lledó, P. M., Merkle, F. T., and ÁlvarezBuylla,A. (2008). Origin and function of olfactory bulb interneuron diversity. Trends Neurosci. 31, 392-400.

Lois, C., and Álvarez-Buylla, A. (1994). Long-distance neuronal migration in the adult mammalian brain. Science 264, 1145-1148.

López-Mascaraque, L., and de Castro, F. (2002). The olfactory bulb as an independent developmental domain. Cell Death Differ. 9, 1279-1286.

López-Mascaraque, L., and de Castro, F. (2004). Protocortex versus protomap: a perspective from the olfactory bulb. Rev. Neurol. 39, 146-155.

López-Mascaraque, L., De Carlos, J. A., and Valverde, F. (1996). Early onset of the rat olfactory bulb projections. Neuroscience 70, 255-266.

Luskin, M. B. (1993). Restricted proliferation and migration of postnatally generated neurons derived from the forebrain subventricular zone. Neuron 11, 173-189.

Luskin, M. B., and Price, J. L. (1982). The distribution of axon collaterals from the olfactory bulb and the nucleus of the horizontal limb of the diagonal band to the olfactory cortex demonstrated by double retrograde labeling techniques. J. Comp. Neurol. 209, 249-263.

Luxenhofer, G., Breer, H., and Strotmann, J. (2008). Differential reaction of outgrowing olfactory neurites monitored in explant culture. J. Comp. Neurol. 509, 580-593.

Ma, L., and Tessier-Lavigne, M. (2007). Dual branch-promoting and branchrepelling actions of Slit/Robo signaling on peripheral and central branches of developing sensory axons. J. Neurosci. 27, 6843-6851.

Malnic, B., Hirono, J., Sato, T., and Buck, L. B. (1999). Combinatorial receptor codes for odors. Cell 96, 713-723.

Mandairon, N., Sacquet, J., Jourdan, F., and Didier, A. (2006). Long-term fate and distribution of newborn cells in the adult mouse olfactory bulb: influences of olfactory deprivation. Neuroscience 141, 443-451.

Mann, F., Ray, S., Harris, W., and Holt, C. (2002). Topographic mapping in dorsoventral axis of the Xenopus retinotectal system depends on signaling through ephrin-B ligands. Neuron 35, 461-473.

Maresh,A., Rodríguez Gil,D., Whitman,M. C., and Greer, C.A. (2008). Principles of glomerular organization in the human olfactory bulb-implications for odor processing. PLoS ONE 3, e2640. doi: 10.1371/journal.pone.0002640.

Marillat, V., Cases, O., N'Guyen-BaCharvet, K. T., Tessier-Lavigne, M., Sotelo, C., and Chedotal, A. (2002). Spatiotemporal expression patterns of slit and robo genes in the rat brain. J. Comp. Neurol. 442, 130-155.

Marín, O., and Rubenstein, J. L. (2003). Cell migration in the forebrain. Annu. Rev. Neurosci. 26, 441-483.

Martínez-Marcos, A. (2009). On the organization of olfactory and vomeronasal cortices. Prog. Neurobiol. 87, 21-30.

Mombaerts, P.(1996). Targeting olfaction. Curr. Opin. Neurobiol. 6, 481-486.

Mombaerts, P. (2001). How smell develops. Nat. Neurosci. 4(Suppl.), 1192-1198.

Mombaerts, P. (2006). Axonal wiring in the mouse olfactory system. Annu. Rev. Cell Dev. Biol. 22, 713-737.

Mouret, A., Gheusi, G., Gabellec, M. M. de Chaumont, F., Olivo-Marin, J. C., and Lledó, P. M. (2008). Learning and survival of newly generated neurons: when time matters. J. Neurosci. 28 , 11511-11516.

Mouret, A., Lepousez, G., Gras, J., Gabellec, M. M., and Lledó, P. M. (2009). Turnover of newborn olfactory bulb neurons optimizes olfaction. J. Neurosci. 29, 12302-12314.

Nacher, J., Alonso-Llosa, G., Rosell, D., and McEwen, B. (2002a). PSA-NCAM expression in the piriform cortex of the adult rat. Modulation by NMDA receptor antagonist administration. Brain Res. 927, 111-121.

Nacher, J., Lanuza, E., and McEwen, B. S. (2002b). Distribution of PSA-NCAM expression in the amygdale of the adult rat. Neuroscience 113, 479-484.

Nakashiba, T., Ikeda, T., Nishimura, S. Tashiro, K., Honjo, T., Culotti, J. G., and Itohara, S. (2000). Netrin-G1: anovel glycosyl phosphatidylinositollinkedmammalian netrin that is functionally divergent from classical netrins. J. Neurosci. 20, 6540-6550.

N'Guyen-Ba-Charvet, K. T., Brose, K., Ma, L., Wang, K. H., Marillat, V., Sotelo, C., Tessier-Lavigne, M., and Chédotal A. (2001). Diversity and specificity of actions of Slit2 proteolytic fragments in axon guidance. J. Neurosci. 21, 4281-4289.

N'Guyen-Ba-Charvet, K. T., Brose, K., Marillat, V., Kidd, T., Goodman, C. S., Tessier-Lavigne, M., Sotelo, C., and Chédotal, A. (1999). Slit2-mediated chemorepulsion and collapse of developing forebrain axons. Neuron 22, 463-473.

N'Guyen-Ba-Charvet, K. T., Di Meglio, T., Fouquet, C., and Chédotal, A. (2008). Robos and slits control the pathfinding and targeting of mouse olfactory sensory axons. J. Neurosci. 28, 4244-4249.

N'Guyen-Ba-Charvet, K. T., Plump, A. S., Tessier-Lavigne, M., and Chedotal, A. (2002). Slit1 and slit2 proteins control the development of the lateral olfactory tract. J. Neurosci. 22, 5473-5480.

Nomura, T., and Osumi, N. (2004). Misrouting of mitral cell progenitors in the Pax6/small eye rat telencephalon. Development 131, 787-796.

O'Leary, D. D. (1989). Do cortical areas emerge from a protocortex? Trends Neurosci. 12, 400-406.

Orioli, D., Henkemeyer, M., Lemke, G., Klein, R., and Pawon, T. (1996). Sek4 and Nuk receptors cooperate in guidance of commissural axons and in palate formation. EMBO J. 15 , 6035-6049.

Pasterkamp, R. J., Peschon, J. J., Spriggs, M. K., and Kolodkin, A. L. (2003) Semaphorin 7A promotes axon outgrowth through integrins and MAPKs. Nature 424, 398-405.

Patel, K., Nash, J. A., Itoh, A., Liu, Z., Sundaresan, V., and Pini, A. (2001). Slit proteins are not dominant chemorepellents for olfactory tract and spinal motor axons. Development 128 , 5031-5037.

Paxinos, G. (2004). The Rat Nervous System, 3rd edn. London, Elsevier Academic Press.

Petreanu, L., and Álvarez-Buylla, A. (2002). Maturation and death of adultborn olfactory bulb granule neurons: role of olfaction. J. Neurosci. 22, 6106-6113.

Pini A. (1993). Chemorepulsion of axons in the developing mammalian central nervous system. Science 261, 95-98.

Pires-Neto, M.A., and Lent, R. (1993). The prenatal development of the anterior commissure in hamsters: pioneer fibers lead the way. Brain Res. Dev. Brain Res. 72, 59-66.

Potter,S.M.,Zheng,C., Koos,D.S.,Feinstein P., Fraser, S. E., and Mombaerts, P. (2001). Structure and emergence of specific olfactory glomeruli in the mouse. J. Neurosci. 21, 9713-9723.

Price, D. J., Kennedy, H., Dehay, C., Zhou, L., Mercier, M., Jossin, Y., Goffinet, A. M., Tissir, F., Blakey, D., and Molnár, Z. (2006). The development of cortical connections. Eur. J. Neurosci. 23, 910-920.

Priest, C. A., and Puche, A. C. (2004). GABAB receptor expression and function in olfactory receptor neuron axon growth. J. Neurobiol. 60, 154-165.

Przyborski, S. A., Knowles, B. B., and Ackerman, S. L. (1998). Embryonic phenotype of Unc5h3 mutant mice suggests chemorepulsion during the formation of the rostral cerebellar boundary. Development 125, 41-50. 
Rakic, P. (1988). Specification of cerebral cortical areas. Science 241, 170-176.

Rakic, P., Ayoub, A. E., Breunig, J. J., and Domínguez, M.H. (2009). Decision by division: making cortical maps. Trends Neurosci. 32, 291-301.

Reed, R. R. (2004). After the holy grail: establishing a molecular basis for mammalian olfaction. Cell 116, 329-336.

Ren, T., Anderson, A., Shen, W. B., Huang, H., Plachez, C., Zhang, J., Mori, S., Kinsman, S. L., and Richards, L. J. (2006). Imaging, anatomical, and molecular analysis of callosal formation in the developing human fetal brain. Anat. Rec. A Discov. Mol. Cell. Evol. Biol. 288, 191-204.

Renzi, M. J., Wexler, T. L., and Raper, J. A. (2000). Olfactory sensory axons expressing a dominant-negative semaphorin receptor enter the CNS early and overshoot their target. Neuron $28,437-447$.

Rochefort, C., Gheusi, G., Vincent, J. D., and Lledó, P. M. (2002). Enriched odor exposure increases the number of newborn neurons in the adult olfactory bulb and improves odor memory. J. Neurosci. 22, 2679-2689.

Rodriguez-Gil, D. J., and Greer, C. A. (2008).Wnt/Frizzled family members mediate olfactory sensory neuron axon extension. J. Comp. Neurol. 511, 301-317.

Saha, B., Hari, P., Huilgol, D., and Tole, S. (2007). Dual role for LIMhomeodomain gene Lhx2 in the formation of the lateral olfactory tract. J. Neurosci. 27, 2290-2297.

Sahay, A., Molliver, M.E., Ginty, D. D., and Kolodkin,A. L. (2003). Semaphorin 3F is critical for development of limbic system circuitry and is required in neurons for selective CNS axon guidance events. J. Neurosci. 23, 6671-6680.

Santacana, M., Heredia, M., and Valverde, F. (1992). Transient pattern of exuberant projections of olfactory axons during development in the rat. Brain Res. Dev. Brain Res. 70, 213-222.

Sarnat, H. B. (2007). Embryology and malformations of the forebrain commissures. Handb. Clin. Neurol. 87, 67-87.

Sarnat, H. B., and Flores-Sarnat, L. (2001). Neuropathologic research strategies in holoprosencephaly. J. Child Neurol. 16, 918-931.

Sato, Y., Hirata, T., Ogawa, M., and Fujisawa, H. (1998). Requirement for early-generated neurons recognized by monoclonal antibody lot 1 in the formation of lateral olfactory tract. J. Neurosci. 18, 7800-7810.

Schwarting, G. A., and Henion, T. R. (2008). Olfactory axon guidance: the modified rules. J. Neurosci. Res. 86, 11-17.
Schwarting, G. A., Kostek, C., Ahmad, N., Dibble, C., Pays, L., and Püschel, A. W. (2000). Semaphorin $3 A$ is required for guidance of olfactory axons in mice. J. Neurosci. 20, 7691-7697.

Schwarting, G. A., Raitcheva, D., Bless, E. P., Ackerman, S. L., and Tobet, S. (2004). Netrin 1-mediated chemoattraction regulates the migratory pathway of LHRH neurons. Eur. J. Neurosci. 19, 11-20.

Schwob, J. E., and Price, J. L. (1984). The development of axonal connections in the central olfactory system of rats. $J$. Comp. Neurol. 223, 177-202.

Schwob, J. E., Szumowski, K. E., and Stasky, A. A. (1992). Olfactory sensory neurons are trophically dependent on the olfactory bulb for their prolonged survival. J. Neurosci. 12, 3896-3919.

Scolnick, J.A., Cui, K., Duggan, C.D., Xuan, S., Yuan, X. B., Efstratiadis, A., and Ngai, J. (2008). Role of IGF signaling in olfactory sensory map formation and axon guidance. Neuron 57, 847-857.

Scott, J.W., McBride, R. L., and Schneider, S. P. (1980). The organization of projections from the olfactory bulb to the piriform cortex and olfactory tubercle in the rat. J. Comp. Neurol. 194, 519-534.

Seki, T., and Arai, Y. (1991). Expression of highly polysialylated NCAM in the neocortex and piriform cortex of the developing and the adult rat. Anat. Embryol. 184, 395-401.

Serafini, T., Colamarino, S. A., Leonardo, E. D., Wang, H., Beddington, R., Skarnes, W. C., and Tessier-Lavigne M. (1996). Netrin-1 is required for commissural axon guidance in the developing vertebrate nervous system. Cell 87, 1001-1014.

Serizawa, S., Miyamichi, K., Takeuchi, H., Yamagishi, Y., Suzuki, M., and Sakano, H. (2006). A neuronal identity code for the odorant receptor-specific and activity-dependent axon sorting. Cell 127, 1057-1069.

Shay, E. L., Greer, C. A., and Treloar, H. B. (2008). Dynamic expression patterns of ECM molecules in the developing mouse olfactory pathway. Dev. Dyn. 237, 1837-1850.

Shen, Y., Mani, S., Donovan, S. L., Schwob, J. E., and Meiri, K. F. (2002). Growthassociated protein- 43 is required for commissural axon guidance in the developing vertebrate nervous system. J. Neurosci. 22, 239-247.

Shipley, M. T., and Adamek, G. D. (1984). The connections of the mouse olfactory bulb: a study using orthograde and retrograde transport of wheat germ agglutinin conjugated to horseradish peroxidase. Brain Res. Bull. 12, 669-688.
Shipley, M. T., and Ennis, M. (1996). Functional organization of olfactory system. J. Neurobiol. 30, 123-176.

Shipley, M. T., Ennis, M., and Puche, A. C. (2004). Olfactory system. In The Rat Nervous System, 3rd edn, G. Paxinos, ed. (London, Elsevier Academic Press), pp. 923-964.

Shu, T., Valentino, K. M., Seaman, C. Cooper, H. M., and Richards, L. J. (2000). Expression of the netrin-1 receptor deleted in colorectal cancer (DCC) is largely confined to projecting neurons in the developing forebrain. $J$. Comp. Neurol. 416, 201-212.

Silver, J., Lorenz, S. E., Wahlsten, D., and Coughlin, J. (1982). Axonal guidance during development of the great cerebral commissures: descriptive and experimental studies, in vivo, on the role of preformed glial pathways. $J$. Comp. Neurol. 210, 10-29.

Soucy, E. R., Albeanu, D. F., Fantana, A. L., Murthy, V.N., and Meister, M. (2009). Precision and diversity in an odor map on the olfactory bulb. Nat. Neurosci. 12, 210-220.

Soussi-Yanicostas, N., de Castro, F., Julliard, K., Perfettini, I., Chédotal, A., and Petit, C. (2002). Anosmin-1 defective in the X-linked form of Kallmann syndrome promotes axonal branch formation from olfactory bulb output neurons. Cell 109, 217-228.

St John, J. A., Clarris, H. J., and Key, B. (2002). Multiple axon guidance cues establish the olfactory topographic map: how do these cues interact? Int J. Dev. Biol. 46, 639-647.

St John, J.A., and Key, B. (2001). Chemically and morphologically identifiable glomeruli in the rat olfactory bulb. $J$. Comp. Neurol. 436, 497-507.

Stein, E., and Tessier-Lavigne, M. (2001) Hierarchical organization of guidance receptors: silencing of netrin attraction by slit through Robo/DCC receptor complex. Science 291, 1928-1938.

Stoeckli, E. T., and Landmesser, L. T. (1995). Axonin-1 Nr-CAM and NgCAM play different roles in the in vivo guidance of chick commissural neurons. Neuron 14, 1165-1179.

Stoeckli,E. T., and Landmesser,L. T. (1998). Axon guidance at choice points. Curr. Opin. Neurobiol. 8, 73-79.

Strotmann, J., Levai, O., Fleischer, J. Schwarzenbacher, K., and Breer, $\mathrm{H}$. (2004). Olfactory receptor proteins in axonal processes of chemosensory neurons. J. Neurosci. 24, 7754-7761.

Sugisaki, N., Hirata, T., Naruse, I., Kawakami, A., Kitsukawa, T., and Fujisawa, H. (1996). Positional cues that are strictly localized in the telencephalon induce preferential growth of mitral cell axons. J. Neurobiol. 29, 127-137.
Suto, F., Ito, K., Uemura, M., Shimizu, M. Shinkawa, Y., Sanbo, M., Shinoda, T., Tsuboi, M., Takashima, S., Yagi, T., and Fujisawa, H. (2005). Plexin-a4 mediates axon-repulsive activities of both secreted and transmembrane semaphorins and plays roles in nerve fiber guidance. J. Neurosci. 25, 3628-3637.

Szabo-Rogers, H.L., Geetha-Loganathan, P., Whiting, C. J., Nimmagadda, S., Fu, K., and Richman, J.M. (2009). Novel skeletogenic patterning roles for the olfactory pit. Development 136, 219-229.

Taniguchi, M., Nagao, H., Takahashi, Y. K., Yamaguchi, M., Mitsui, S., Yagi, T., Mori, K., and Shimizu, T. (2003). Distorted odor maps in the olfactory bulb of semaphorin 3A-deficient mice. J. Neurosci. 23, 1390-1397.

Teillon, S. M., Yiu, G., and Walsh, C. A. (2003). Reelin is expressed in the accessory olfactory system, but is not a guidance cue for vomeronasal axons. Brain Res. Dev. Brain Res. 140, 303-307.

Tessier-Lavigne, M., and Goodman, C. S. (1996). The molecular biology of axon guidance. Science 274, 1123-1133.

Tissir, F., Bar,I., Jossin, Y., De Backer, O., and Goffinet, A. M. (2005). Protocadherin Celsr3 is crucial in axonal tract development. Nat. Neurosci. 8, 451-457.

Tiveron, M. C., and Cremer, H. (2008). CXCL12/CXCR4 signalling in neuronal cell migration. Curr. Opin. Neurobiol. 18, 237-244.

Toba, Y., Tiong, J. D., Ma, Q., and Wray, S. (2008). CXCR4/SDF-1 system modulates development of GnRH-1 neurons and the olfactory system. $\mathrm{Dev}$. Neurobiol. 68, 487-503.

Tran, H., Chen, H., Walz, A., Posthumus, J. C., and Gong, Q. (2008). Influence of olfactory epithelium on mitral/ tufted cell dendritic outgrowth. PLoS ONE 3, e3816. doi:10.1371/journal. pone.0003816.

Treloar, H. B., Feinstein, P., Mombaerts, P., and Greer, C. A. (2002). Specificity of glomerular targeting by olfactory sensory axons. J. Neurosci. 22, 2469-2477.

Treloar, H. B., Gabeau, D., Yoshihara, Y., Mori, K., and Greer, C. A. (2003) Inverse expression of olfactory cell adhesion molecule in a subset of olfactory axons and a subset of mitral/ tufted cells in the developing rat main olfactory bulb. J. Comp. Neurol. 458, 389-403.

Treloar, H. B., Nurcombe, V., and Key, B. (1996). Expression of extracellular matrix molecules in the embryonic rat olfactory pathway. J. Neurobiol. 31, 41-55.

Treloar, H. B., Ray, A., Dinglasan, L. A., Schachner, M., and Greer, C.A. (2009). Tenascin-C is an inhibitory boundary 
molecule in the developing olfactory bulb. J. Neurosci. 29, 9405-9416.

Trinh, K., and Storm, D. R. (2003). Vomeronasal organ detects odorants in absence of signaling through main olfactory epithelium. Nat. Neurosci. 6, 519-525.

Valverde, F. (1965). Studies on the Piriform Lobe. Harvard, Harvard University Press.

Valverde, F., Santacana, M., and Heredia, M. (1992). Formation of an olfactory glomerulus: morphological aspects of development and organization. Neuroscience 49, 255-275.

von Campenhausen, H., Yoshihara, Y., and Mori, K. (1997). OCAM reveals segregated mitral/tufted cell pathways in developing accessory olfactory bulb. Neuroreport 28, 2607-2612.

Walz, A., Mombaerts, P., Greer, C. A., and Treloar, H. B. (2006a). Disrupted compartmental organization of axons and dendrites within olfactory glomeruli of mice deficient in the olfactory cell adhesion molecule, OCAM. Mol. Cell Neurosci. 32, 1-14.

Walz, A., Omura, M., and Mombaerts, P. (2006b). Development and topography of the lateral olfactory tract in the mouse: imaging by genetically encoded and injected fluorescent markers. J. Neurobiol. 66, 835-846.

Walz, A., Rodriguez, I., and Mombaerts, P. (2002). Aberrant sensory innervation of the olfactory bulb in neuropilin-2 mutant mice. J. Neurosci. 22, 4025-4035.

Wang, K. H., Brose, K., Arnott, D., Kidd, T., Goodman, C. S., Henzel, W., and Tessier-Lavigne, M. (1999). Biochemical purification of a mammalian slit protein as a positive regulator of sensory axon elongation and branching. Cell 96, 71-784.

Wang, Y., Thekdi, N., Smallwood, P. M., Macke, J. P., and Nathans, J. (2002). Frizzled-3 is required for the development of major fiber tracts in the rostral CNS. J. Neurosci. 22, 8563-8573.

Wang, Y., Zhang, J., Mori, S., and Nathans, J. (2006). Axonal growth and guidance defects in Frizzled3 knock-out mice: a comparison of diffusion tensor magnetic resonance imaging, neurofilament staining, and genetically directed cell labeling. J. Neurosci. 26, 355-364.

Watanabe, K., Tamamaki, N., Furuta, T., Ackerman, S. L., Ikenaka, K., and Ono, K. (2006). Dorsally derived netrin 1 provides an inhibitory cue and elaborates the 'waiting period' for primary sensory axons in the developing spinal cord. Development 133, 1379-1387.

Weiler,E., and Farbman, A.I. (1999). Mitral cell loss following lateral olfactory tract transection increases proliferation density in rat olfactory epithelium. Eur. J. Neurosci. 11,3265-3275.

Whitesides, J. G., and LaMantia, A.-S. (1998). Differential adhesion and the initial assembly of the mammalian olfactory nerve. J. Comp. Neurol. 373, 240-254.

Wu, H. H., Ivkovic, S., Murray, R. C., Jaramillo, S., Lyons, K. M., Johnson, J. E., and Calof, A. L. (2003). Autoregulation of neurogenesis by GDF11. Neuron 37, 197-207.

Yamaguchi, M., and Mori, K. (2005). Critical period for sensory experiencedependent survival of newly generated granule cells in the adult mouse olfactory bulb. Proc. Natl. Acad. Sci. U.S.A. 102, 9697-9702.

Yamatani, H., Sato, Y., Fujisawa, H., and Hirata, T. (2004). Chronotopic organization of olfactory bulb axons in the lateral olfactory tract. J. Comp. Neurol. $475,247-260$.

Yoshihara, Y., Kawasaki, M., Tamada, A., Fujita, H., Hayashi, H., Kagamiyama, H., and Mori, K. (1997). OCAM: a new member of the neural cell adhesion molecule family related to zone-to-zone projection of olfactory and vomeronasal axons. J. Neurosci. $17,5830-5842$.

Yu, C.R., Power,J., Barnea, G.,O’Donnell, S. Brown, H. E., Osborne, J., Axel, R., and Gogos, JA. (2004). Spontaneous neural activity is required for the establishment and maintenance of the olfactory sensory map. Neuron 42, 553-566.

Zhang, L. I., and Poo, M. M. (2001). Electrical activity and development of neural circuits. Nat. Neurosci. 4(Suppl.), 1207-1214.

Zhang, X., and Firestein, S. (2002). The olfactory receptor gene superfamily of the mouse. Nat. Neurosci. 5, 124-133.

Zhao, H., and Reed, R. R. (2001). X inactivation of the OCNC1 channel gene reveals a role for activity-dependent competition in the olfactory system. Cell 104, 651-660.

Zheng, C., Feinstein, P., Bozza, T. Rodriguez, I., and Mombaerts, P. (2000). Peripheral olfactory projections are differentially affected in mice deficient in a cyclic nucleotide-gated channel subunit. Neuron 26, 81-91.

Zheng, J. Q., and Poo, M. M. (2007). Calcium signaling in neuronal motility. Annu. Rev. Cell. Dev. Biol. 23, 375-404.

Zhou, C., Qiu, Y., Pereira, F. A., Crair, M. C., Tsai, S.Y., and Tsai, M. J. (1999). The nuclear orphan receptor COUP-TFI is required for differentiation of subplate neurons and guidance of thalamocortical axons. Neuron 24, 847-859.

Zhou, L., Bar, I., Achouri, Y., Campbell, K., De Backer, O., Hebert, J. M., Jones, K., Kessaris, N., de Rouvroit, C. L., O'Leary, D., Richardson, W. D., Goffinet, A. M., and Tissir, F. (2008). Early forebrain wiring: genetic dissection using conditional Celsr3 mutant mice. Science 320, 946-949.

Zou, D. J., Chesler, A. T., Le Pichon, C. E., Kuznetsov, A., Pei, X., Hwang, E. L., and Firestein, S. (2007). Absence of adenylyl cyclase 3 perturbs peripheral olfactory projections in mice. $J$. Neurosci. 27, 6675-6683.
Zou, D. J., Feinstein, P., Rivers, A. L., Mathews, G. A., Kim, A., Greer, C. A., Mombaerts, P., and Firestein, S. (2004). Postnatal refinement of peripheral olfactory projections. Science 304, 1976-1979.

Zou, Y., Stoeckli, E., Chen, H., and TessierLavigne, M. (2000). Squeezing axons out of the gray matter: a role for slit and semaphorin proteins from midline and ventral spinal cord. Cell 102, 363-375.

Zou, Z., Horowitz, L. F., Montmayeur, J. P., Snapper, S., and Buck, L. B. (2001). Genetic tracing reveals a stereotyped sensory map in the olfactory cortex. Nature 414, 173-179.

Zou, Z., Horowitz, L. F., Montmayeur, J. P., Snapper, S., and Buck, L. B. (2008). Genetic tracing reveals a stereotyped sensory map in the olfactory cortex. Nature 452, 120.

Conflict of Interest Statement: The author declares that the research was conducted in the absence of any commercial or financial relationships that could be construed as a potential conflict of interest.

Received: 21 July 2009; paper pending published: 08 August 2009; accepted: 04 November 2009; published online: 04 December 2009

Citation: de Castro F (2009) Wiring olfaction: the cellular and molecular mechanisms that guide the development of synaptic connections from the nose to the cortex. Front. Neurosci. 3:52. doi: 10.3389/neuro.22.004.2009

This article was submitted to Frontiers in Neurogenesis, a specialty of Frontiers in Neuroscience.

Copyright $\odot 2009$ de Castro. This is an open-access article subject to an exclusive license agreement between the authors and the Frontiers Research Foundation, which permits unrestricted use, distribution, and reproduction in any medium, provided the original authors and source are credited. 